\title{
Hidden Treasures at McGill: A Survey of Manuscripts and Historical Documents
}

\author{
by Raymond Klibansky
}

\begin{abstract}
This study is designed to convey an idea of the uealth of material preserved in the various collections of McGill University. In particular, attention is drawn to the many important documents that bave remained unnoticed and to the unexpected discoveries to be made. In the survey of the Greek manuscripts, account is taken of the papyri found in Egypt of the second and third century, A.D. Among the charters found in the Latin collection there are several by Popes of the Italian Renaissance, two of them issued by well-known bumanist scholars, as well as a surprisingly large number linked with successive doges of Venice. The survey of manuscripts bearing on English literature and history mentions unpublished letters by Hannab More and her sisters, James Forbes' travel journal, the Hardinge papers, as well as autographs of many nineteenth century writers. It focuses on the outstanding collection concerning David Hume in which no less than 50 letters in his hand have been found as well as several books from his library. The survey is followed by a summary description of important source material bearing on the history of Canada, both under the French and the English regime. A further section deals with the documents illustrating the history of science from the thirteenth century to the present. They include Newton's copy of his Opticks, with corrections in bis own hand; and letters by Babbage, Faraday, Herschel and other outstanding scientists. In a sketch of the main special collections, particular mention is made of the books from Kierkegaard's library and the remarkable Fishstein collection containing rare items of Yiddish literature.
\end{abstract}

Cette étude vise à donner une idée des richesses que renferment les différentes collections de l'université McGill. En particulier, elle signale de nombreux documents, jusqu'ici inconnus, et fait pressentir les découvertes inattendues qui attendent le chercheur. Au chapitre des manuscrits grecs, mention est faite des papyrus des deuxième et troisième siècles de notre ère découverts en Égyte. La collection d'ouvrages en latin comprend plusieurs chartes de papes de la Renaissance italienne, dont deux publiées par d'éminents bumanistes, ainsi qu'un nombre surprenant de chartes émanant des doges de Venise. Parmi les manuscrits consacrés à la littérature et l'histoire anglaises figurent des lettres inédites d'Hannab More et de ses soeurs, le carnet de voyage de James Forbes, le fonds de Hardinge ainsi que les autographes de nombreux écrivains du dix-neuvième siècle. Ce tour d'borizon est tout particulièrement consacré à la collection impressionnante de documents se rapportant à David Hume qui comprend non moins de 50 lettres écrites de sa main ainsi que plusieurs livres de sa bibliothèque personnelle. Cette étude est suivie d'une description sommaire des principaux documents sur l'bistoire du Canada, sous les régimes français et anglais. Un autre chapitre est consacré aux documents illustrant l'bistoire des sciences, du treizième siècle à nos jours. Parmi eux figurent un exemplaire de l'Opticks de Newton, corrigé de sa main, ainsi que des lettres de Babbage, Faraday, Herschel et d'autres grands bommes de science. L'apergu sommaire des principales collections spéciales mentionne en particulier les lives de la bibliothèque personnelle de Kierkegaard et la remarquable collection Fishstein qui réunit des exemplaires rarissimes de la littérature yiddish. 


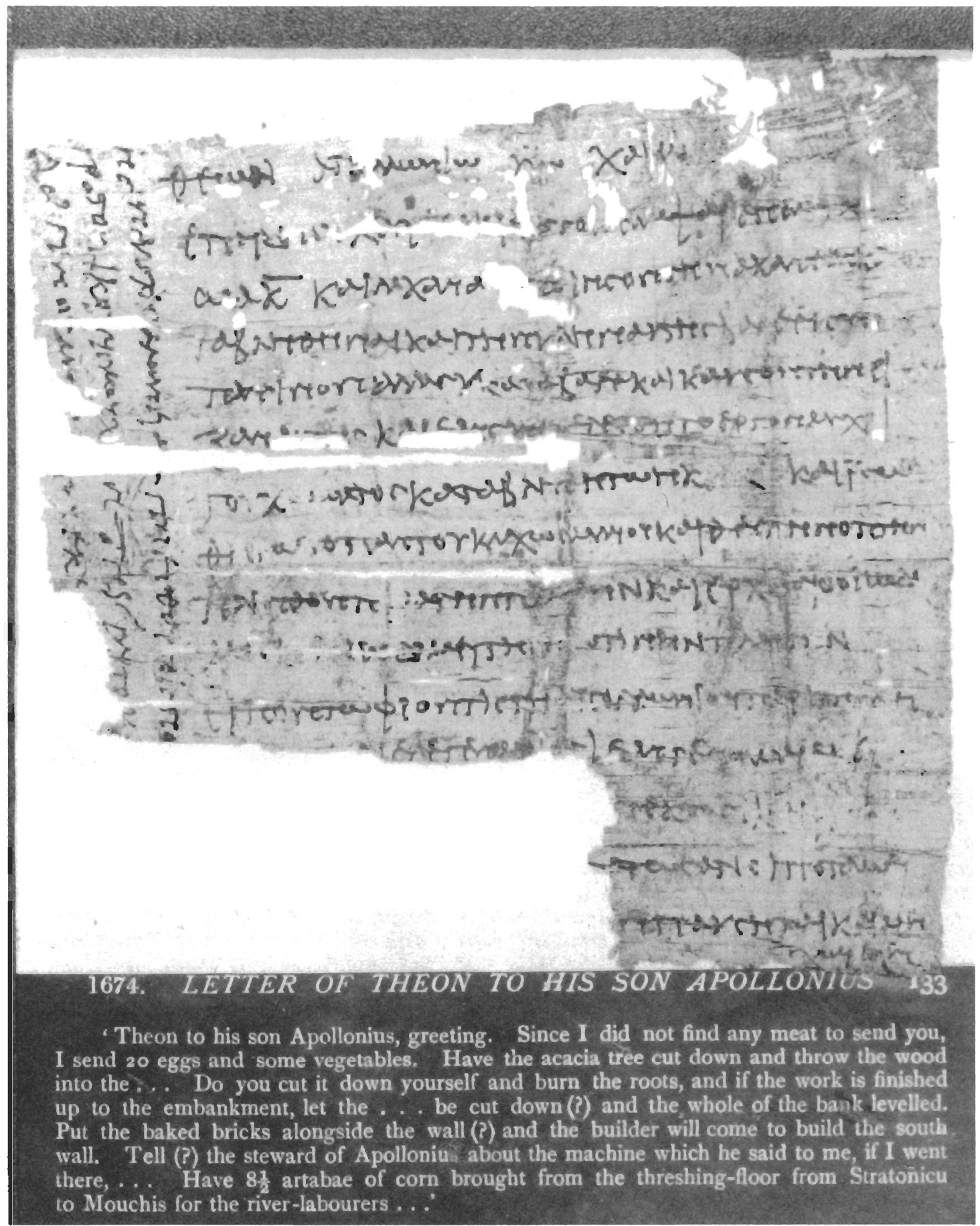

rigure 1. Greek papyrus, Oxyrhynchus no. 1674, 3 rd century A.D. 
I $t$ is the duty of any library of scholarly standing to make its collection of manuscripts accessible by insuring that its holdings are known. Most of the manuscripts may have been presented by generous donors or bought by successive librarians. That these holdings should remain unknown, is either contrary to the donors' intention or a waste of university money. It cannot be justified. I venture to express the hope that McGill will soon, like other university libraries, be able to present a well-prepared detailed catalogue of its manuscripts, available to scholars throughout the world.

The following survey is designed to draw attention to the wealth of material preserved at McGill, to convey an idea of its distribution among a great variety of traditions and languages, and to point to some of the remarkable documents which have remained unnoticed so far.

\section{THE PRESENT SITUATION}

The McGill collections are divided among various institutions which form part of the University: the bulk of Western manuscripts and not a few Oriental ones are under the care of the Rare Books and Special Collections Department (RBD) of the McLennan Library. The majority of Oriental manuscripts are housed in the library of the Institute of Islamic Studies, the BlackerWood Library of Biology, and the Osler Library. The collection of manuscripts concerning the history of medicine and kindred subjects in the history of science forms part of the Osler Library in the McIntyre Medical Sciences Building.

Cuneiform tablets, cylinder seals, a few Egyptian papyri and examples of Sinhalese documents on strips of palm leaves are preserved both in the Redpath Museum and - together with a few Greek papyri - in RBD.

In addition to one Latin codex, the Religious Studies Library possesses five Armenian manuscripts; together with 8 other Armenian manuscripts and fragments they are housed in RBD. Two of these are described in A.K. Sanjian's A Catalogue of Medieval Armenian Manuscripts in the United States. '
The McCord Museum of Canadian History contains many important documents concerning the history of Canada, but it also has a series of parchments, to which little attention has been paid so far, dealing with French history from the end of the fifteenth to the seventeenth century.

Some interesting papers illustrating early Canadian history are part of the Lande Collection of Canadiana on the fourth floor of the McLennan Library.

Finally, the University Archives house, first and foremost, the administrative and legal records of the University as a whole from its beginnings, as well as that of its component parts, and much material relating to generations of teachers and students.

As to the total number of manuscript documents in these collections, it is still too early to provide a precise figure. At a rough estimate, they amount to several thousand items. Since they have never been sorted according to language or time of origin, they present a bewildering mass. The first task, therefore, is to make an end to this haphazard arrangement by grouping them into the various languages. The following outline is designed to serve this end.

The manuscripts fall into two main groups: (I) Oriental and (II) Western.

\section{(I) Oriental}

The collection of Islamic manuscripts contains over 650 volumes written in Arabic, Persian, Ottoman Turkish or Urdu. The Arabic and Persian manuscripts are by far the most numerous, constituting well over $90 \%$ of the whole. Thanks to the initiative of the Director of Libraries, Dr. Eric Ormsby, the description has been taken in hand. The Arabic manuscripts, about 280 volumes, have been examined by Adam Gacek, Librarian of the Istamic Studies Library. To a large extent, they represent a Shiite collection from Iran; a few come from Turkey. They concern Islamic sacred law and theology but also philosophy, in particular Avicenna with commentators. It is planned to publish a catalogue which will take the place of the very brief and insufficient summary at present available in North American Collections of Islamic Manuscripts. ${ }^{2}$ 
A rough list of the Muslim manuscripts from India at the Blacker-Wood I.ibrary is contained in A Dictionary Catalogue of the Blacker-Wood Library of Zoology and Ornithology. ${ }^{3}$ 'They were collected in India in 1926-29 for Dr. Casey Wood, by Wladimir Ivanov, formerly Assistant Keeper of Muslim manuscripts in the Asiatic Museum at the Imperial Russian Academy of Sciences at St. Petersburg and afterwards cataloguer of manuscripts at the Asiatic Society of Bengal in Calcutta. Of the 320 items bound in 238 volumes, most are in Persian, the language of the Mughal court and, generally, of culture in Muslim India until modern times. There are also 75 manuscripts in Arabic, the language of religion, and half a dozen more recent ones in Urdu, the popular language.

The Osler Library contains 79 Arabic and 68 Persian manuscripts. Many of these come from Dr. Casey Wood's ophthalmologic collection, of which a substantial part was acquired from Max Meyerhof, the well-known Islamic scholar in Cairo. A series of 19 Sinhalese medical codices was also presented by Casey Wood. A checklist of manuscripts on general medical topics by Wladimir Ivanov is published in the Bibliolbeca Osleriana (see below) which also contains notes regarding a few other Oriental manuscripts.

RBD houses not only 40 manuscripts in Arabic, Persian and Ottoman Turkish, it also contains, as I learned from A. Gacek, a remarkable collection of over 200 specimens of the finest Arabic calligraphy which he discovered there together with a collection of excuisite book-covers, many of them from Srinagar (Kashmir).

Very brief descriptions of the approximately 200 manuscripts in Indian languages preserved in RBD, Blacker-Wood and in Osler - among which there are fragments from the Rigveda and the Mahabharata - are found scattered in the Census of Indic Manuscripts in the United States and Canada. ${ }^{4}$

One Egyptian item in the Redpath Museum has been described and illustrated in four plates by David Berg in the Journal of the Society for the Studies of Egyptian Antiquities. 5

The numerous cuneiform tablets and cylinder seals in the Redpath Museum and in RBD were examined by the Royal Inscriptions of Mesopotamia Project at the University of
Toronto in 1983; so far no detailed description of contents has been provided. The brief account of nine cunciform documents given in 1922 in a letter by Dr. C.G. Gadd of the British Muscum is still the best guide for at least a part of the collection of the Redpath Museum. A NeoBabylonian tablet with omens and divinations derived from the state of the liver is considered to be of particular importance.

A systematic investigation by experts is required to sift the precious Babylonian and Egyptian documents from the fakes which are uncloubtedly found in these collections.

\section{(II) Western}

Without any distinction of languages, descriptions of the Western manuscripts are at present found in the following four lists:

\section{A) The de Ricci Census}

In the first place, any scholar would consult the Census of Medieval and Renaissance Manuscripts in the United States and Canada, by Seymour de Ricci." In this Census, the manuscripts of the "Library of McGill University" (the collection now in RBD) are listed on pp.2203-2229, followed by the description of the documents of the Mccord Museum, pp.2230-2231. The descriptions are the result of de Ricci's visit to McGill in 1932 which, he says, "was a short one." He adds that "he would have been glad to devote more time to the single leaves and initials from Italian choir books; they would repay a close study."7

The Census considers only the manuscripts written before 1600 - a total of 178 in RBD, 31 in Osler, 18 in the McCord Museum; but even with regard to these, it is far from being complete.

No one equalled de Ricci's knowledge of sales catalogues. He was able to trace the history of almost any manuscript which, since the beginning of the nineteenth century, had changed hands in public auctions or was listed in booksellers' catalogues. His knowledge of manuscripts and their fate was uncommon. However, his descriptions of the McGill holdings are summary and not always reliable. They show clear signs of haste and, alas, sometimes contain astonishing errors. To give two examples: MS de Ricci 112 is described as a "treatise in a German dialect"; it is in fact in Old-Slavonic. MS cie Ricci 
4 is presented as "in Armenian with Greek portions"; it is a Greek manuscript with musical notations which have wrongly been taken to be Armenian script.

In the Supplement to the Census published in $1962^{8}$ no account is taken of the numerous additions of manuscripts before 1600 made since de Ricci's visit in 1932; nor does it contain any corrections whatsoever of his descriptions of McGill manuscripts.

\section{B) Bibliotheca Osleriana}

The manuscripts are listed in Sir William Osler's Bibliotheca Osleriana. A Catalogue of Books Illustrating the History of Medicine and Science. Collected, Arranged, and Annotated by Sir William Osler, Bt. and Bequeathed to McGill University. ${ }^{9}$ The descriptions are brief, but helpful and on the whole accurate. Since the completion of the catalogue several accessions have been added to the collection.

\section{C) European and American Manuscripts}

A mimeographed handlist of European and American manuscripts, ${ }^{10}$ completed in 1962 , aims at listing the manuscripts of the University Library "exclusive of the mediaeval and oriental manuscripts and of the Autograph Letters collection." It lists 771 items. Some of these appear also in de Ricci's list; however, there is no indication of the discrepancy between the classification in de Ricci and the shelfmarks given in the handlist. The descriptions are brief and in not a few cases erroneous.

D) Union List of Manuscripts in Canadian Repositories

The first attempt at providing a summary handlist of all manuscripts in Canadian libraries and archives in a series of volumes published in Ottawa by the Public Archives of Canada (revised edition, vols. 1-2, 1975; and four Supplements, the last one of 1981-82, published in 1985), in itself a laudable enterprise, fails to give an adequate account of the material found at McGill. Many of the precious documents mentioned in the following pages have remained unnoticed.

E) Guide to Archival Resources at McGill University

A Guide to Archival Resources at McGill University ${ }^{11}$ consists of three volumes: Volume I, The Archival Records of McGill University, presents a useful survey of all the University records. Volume II, Private Papers held at McGill University (Part I), lists the material concerning teachers and students as well as brief indications concerning documents in the fields of medicine and the sciences, business and cconomy. Volume III, Private Papers held at Mc Gill University (Part II), lists documents concerning war and the military, politics and the government, culture, literature and the arts, professions and trades, social and philanthropic organisations, religious and fraternal organisations, family and private life, travel and exploration. The parts dealing with historical and literary manuscripts often follow the indications provided in European and American Manuscripts above, adding some further information. In some cases, errors of the latter have been repeated. Useful as this survey is, it is incomplete.

To my surprise, I found that McGill possesses numerous documents ranging from the fourteenth to the nineteenth century which are not listed in any of the foregoing catalogues. Several of these are of considerable literary interest.

\section{CLASSIFICATION}

Arranged according to countries and languages, the manuscripts, historical documents and papers are distributed as follows:

\section{(I) Greek}

A) Papyri

RBD contains a collection of five Greek papyri, found in Egypt, of the second and third century A.D.: Oxyrhynchus nr. 1517, A.D. 272 or 278 , contains an official account of money payments, probably for oil; nr. 1541, A.D. 192, is a receipt for payment by two persons, one of them a Roman citizen; nr, 1555, A.D. 260 to 261 , contains two declarations under oath concerning surety, probably for appearance at an inquiry; nr. 1685 , A.D. 158 , is part of a badlyspelled lease of two lots of land from a woman to two Persians; nr. 1674, third century, is the oldest personal letter at McGill (Figure 1). It begins: "Theon to his son Apollonius, greeting. Since I did not find any meat to send you, I send 20 eggs and some vegetables." But he is also 
expected to carry out some work on his father's estate. "Have the acacia tree cut down and throw the wood into the (?)... Do you cut it down yourself and burn the roots... Put the baked bricks alongside the wall and the builder will come to build the south wall." 12

There is, moreover, a small framed papyrus fragment of the fifth century.

\section{B) Manuscripts}

The collection contains no classical texts, but gospels, manuscripts of liturgical and musical interest as well as one eighteenth-century book of popular medicine with a glossary of medical terms. De Ricci's description of the items of religious content have to be corrected in several places with respect to dating. The interesting question of the authenticity of the illustrated headpiece of the lectionary of one of the gospels (de Ricci 3) has been solved by Professor George Galavaris of McGill University, who has agreed to prepare a detailed catalogue of the 12 Greek manuscripts in the collection at McGill. Special mention should be made of a small palimpsest fragment (MS Coptic 2) of the fifth century, with a Coptic magic formula superimposed at a somewhat later date.

The difficulties confronting those who set out to describe manuscripts without having some expert knowledge of the literature is shown by an item (M 228 Bd Box V) disregarded by de Ricci and described in the McGill lists above as an original Greek poem by Dick Aberdaron entitled "An Ode of Harps," dated "circa 1820." In fact, the manuscript of ten small pages is a Greek-orthodox poem, describing not harps, but the strings of the lyre as a symbol of the Trinity. "Dick Aberdaron" is not the author but the nickname of the scribe who copied this text for "'Turner" whom we take to be William Turner, the British diplomat and correspondent of Byron, who was based in Constantinople from 1812 to 1816 and returned there later as Secretary to the British Embassy. In his threevolume Journal of a Tour in the Levant, dedicated to George Canning, ${ }^{13}$ Turner reports his visits to the islands and mainland of Greece; he expresses his great interest in "Romaick" (that is Byzantine) literature and speaks of his having collected everything he could find relating to this subject. The identification of William Turner is reinforced by a note on the manuscript signed "M. Turner," who states that the poem was copied for his father; William Turner's son bore the name Mansfield.

\section{(II) Latin}

There are few texts of classical authors Cicero, De amicitia, De senectute, Paradoxa Stoicorum (de Ricci 136), Cicero, De officiis (de Ricci 137); an imperfect copy of Ovid's Fasti (de Ricci 135); Frontinus, Stratagemata (de Ricci 139). They are all of Italian origin, dating from the middle or the later half of the fifteenth century; compared with the numerous extant witnesses of these texts, they do not possess any particular distinction. The same applies to the major part of the patristic and mediaeval manuscripts.

The collection contains many illustrated choirbooks and no less than 80 miniatures and initials, most of them bequeathed by wellmeaning donors, who were unaware of the fact that by acquiring single leaves or, worse still, initials cut out of manuscripts, they encouraged the vandalism of unscrupulous booksellers. A further forty vellum leaves and initials are not listed in de Ricci; most of them come from liturgical manuscripts, a few contain fragments from the Sentences of Petrus Lombardus and a piece on canon law. The existing descriptions are based on those provided by the booksellers from whom the leaves were acquired; they merit little credence. For instance, those from a Roman breviary of 1464 are said to come from the "Cistercian Abbey of Lucca near Hanover," Lucca being a mistake for Loccum.

There are only a few patristic texts, all of the fifteenth century: Augustinus De libero arbitrio (de Ricci 113), written in Venice, and Isidorus De summo bono (de Ricci 1 15), from Northern Italy. A third, not mentioned in de Ricci's catalogue, is St. Jerome's Dialogue with Pelagius, written in a German hand, about 1470 . It is bound in at the end of an incunable, Paulus de Sancta Maria's Scrutinium scripturarum (Strasburg, ca. 1471) and follows upon another manuscript, written slightly later, also in a German hand, bound in the same volume, Peter of Blois' Glosula moralis super lob (= Compendium in Job, Patrologia Latina 207, col. 795-826), dedicated to Henry II, King of England.

The bulk of the collection consists of biblical and liturgical manuscripts, lectionaries, missals, 


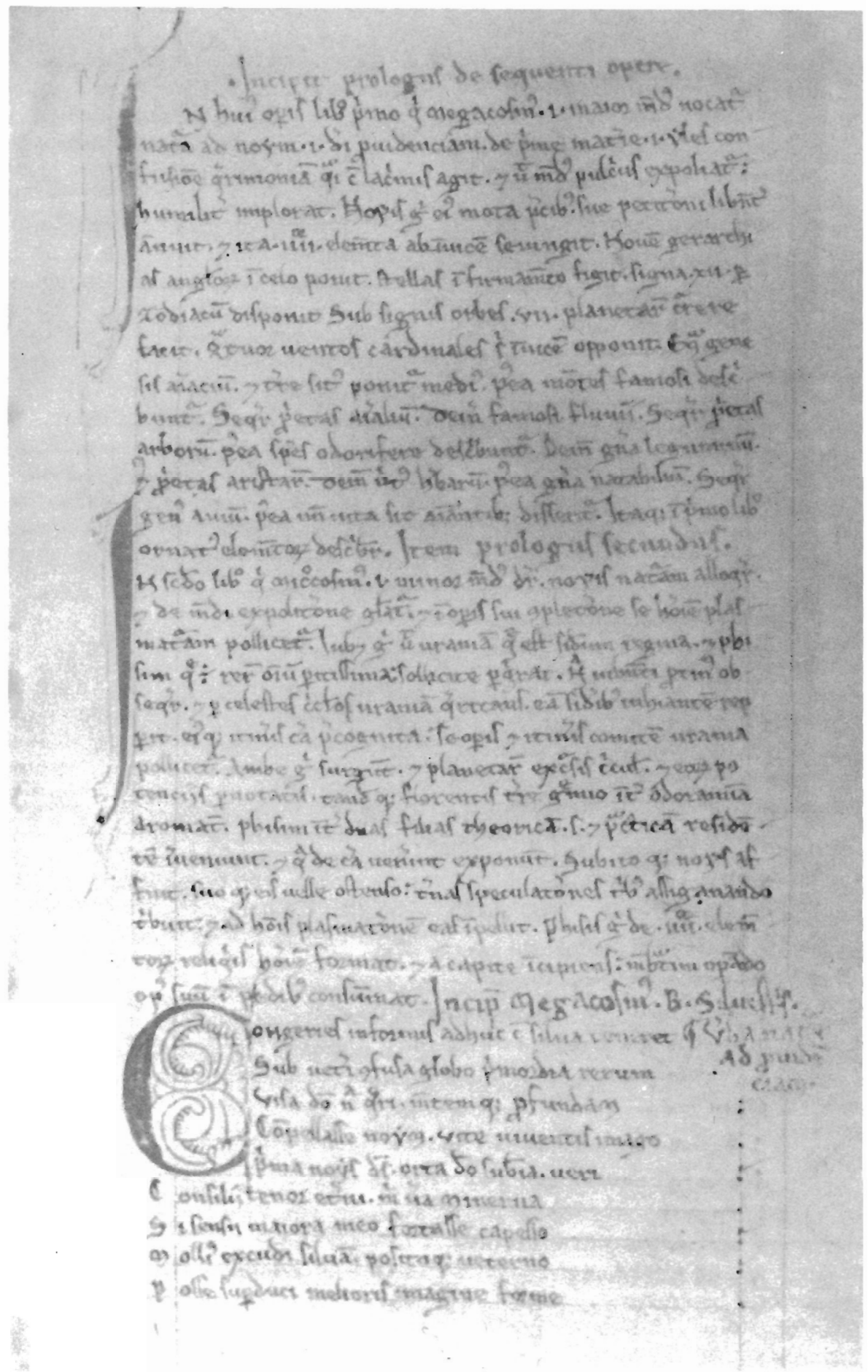

Figure 2. Bernardus Silvestris, De mundi universitate, fol. $1^{\mathrm{r}}$ (MS Latin 1 ). 
Books of Hours, legends of the Saints, sermons and books on canon law, none of them older than the thirteenth century. Over fifty of these are listed by de Ricci, to which three Books of Hours have been added (MS Latin 99a, MS Latin $99 \mathrm{~b}$, MS Latin 108a). Some of the miniatures and initials are of good quality; many others are no more than average.

One codex of the fourteenth century (de Ricci 134) has a particular relevance for the history of astronomy. It contains a commentary on John of Hollywood's Sphera and various other treatises, followed at the end by a short treatise (not recognized in Lynn Thorndike's brief description) on the names of the Devil (fol. $29^{\prime \prime}-30^{\mathrm{r}}$ ), going back ultimately to Isidorus and Jerome. This will be published separately.

As well as many medical manuscripts, the Osler Library has a copy of Michael Scotus' translation, made in the early thirteenth century (from an Arabic version of the early ninth century), of Aristotle's Historia animalium, with parts of a commentary (Osler 238; Aristoteles latinus ed. G. Lacombe, no. 14), which is misleadingly called De animalibus, and a copy, written in $\mathbf{1 4 3 7}$, of the Liber de homine and the Quaestiones de bono by Albertus Magnus (Osler 7506). This manuscript, in a neat contemporary binding of stamped brown leather and two clasps, has two flyleaves in parchment (counted by a modern hand as fol. 1 and 289), which contain - not, as the Osler catalogue states, a "treatise on prophecy," but - a long fragment, in a hand of the fourteenth century, on philosophy (in particular, on the various definitions, the divisions and the 'symbolic' representation of philosophy), and on the liberal arts.

The Library also contains two manuscripts of special interest, one for the history of astrology, the other for the history of alchemy:

MS Osler 7513, written about the middle of the fifteenth century, is described in the Osler catalogue as Summa iudicialis astronomie. According to the introduction, it bears in fact the title De interrogationibus, since it deals with that part of astrology which concerns specific questions. It provides answers to such diverse problems as whether or not there will be war between two armies; whether there was one thief or more; whether the thief was male or female; whether an object to be sold should be priced highly or not. The author proposes to collect and to sum up the relevant doctrines of all the important writers, "antiqui et moderni," singling out in particular Ptolemy, Dorotheus, "Aristotle" and the Arab masters Alkindi, Abû Ma'săr, Abenragel, Messahalā, Avicenna, but also "Guido," that is Guido Bonatti whom Dante had, with other prominent soothsayers like Michael Scott, banished to Hell for their deceitful arts (Inferno XX, 115, ff.). In fact, the author often follows Bonatti, for instance in his detailed description of those born under Saturn. They are of melancholy temperament and characterised by a string of unpleasant attributes. This manuscript was owned by the Venetian nobleman, friend of Pope Julius II, Cardinal of St. Marc (146I-1523) and patron of the arts, Domenico Grimani, the same who, as a good Venetian patriot, had arranged for the dispatches from the Milanese embassy at the Vatican to the Duke of Milan to be intercepted near Rome, and sent to Venice.

MS Osler 480 , written on parchment in a neat hand of the fifteenth century, contains an elaborate treatise on alchemy, entitled Liber de anima by the author, who claims to be Avicenna. Since this book, in dialogue form, totally differs from Avicenna's book of the same title, well-known to, and used by, mediaeval philosophers in discussing the nature of the soul and problems of psychology, the attribution of this work on alchemy is now generally rejected in spite of the fact that such a careful scholar as Berthelot in his La chimie au Moyen-Age sees no good reasons to deny his authorship. Yet the criticism of alchemy in Avicenna's Epistle on this subject (now available in Anawati's French translation) makes the attribution to him untenable. As has been shown by Ruska (in Isis, vol. 21), the Arabic original was composed in Spain long after Avicenna's death. The Latin translation, which found many admiring readers, dates from the first part of the thirteenth century. In any case, the influence of this work in which the principles of Aristotelian logic are applied to alchemy is beyond doubt. It is guided by the thought that anything in the world is constituted by the elements; that each of these is in principle transformable into the others; that it is within the power of man to effect this transformation and that by his actions he does bring to fruition what is hidden in nature. In its Latin form, it was available in the thirtecnth 
century and frequently quoted as authority on the subject in Vincent of Beauvais's Speculum naturale, the leading encyclopaedia of the time; it is also used in Albert the Great's $D e$ mineralibus. A printed version appeared in Artis chemicae principes, Basle 1572.

This Osler manuscript is of particular interest on account of the remarks made at the end of the lengthy work (fol $227^{\circ}$ ) by the man who owned it at the beginning of the sixteenth century: "In hoc autem libro Polydorus Comes Cabaliancnsis invenit lapidem philosophorum verissimum." Hence, if we attach credence to his claim, Polydore, comte de Châlon (surSaone), found in this book the philosophers' stone. It is no surprise to see him providing further information as follows: "Quare sine dubio faciebat mirabilia in vita sua." (Therefore, without any doubt, he performed miracles in his life). He continues, "I beseech you all, you men of letters, to have this book with you when you eat, you drink, you sleep and whatever else you may do. For, if you take care, your efforts will not be in vain. Leave all other books aside and read only this one which is magister magistorum' (the master of masters). You will have a precious reward." He adds: "In cujus fidem et testimonium meum solitum signum apposui relligionis [sic]." His signature is indeed appended, vouching for the truth of his statement.

Among the mediaeval manuscripts, the most interesting is a copy of the famous cosmology in poetic form by Bernardus Silvestris, the twelfth-century master of Tours, De mundi universitate (Figure 2). The McGill copy (RBD MS Latin 1), written at the beginning of the thirteenth century and not yet listed anywhere, was unknown to the recent editor of Bernardus. ${ }^{14}$ The manuscript affords a further proof of the wide diffusion of this important text. It omits the dedication to Thicrry, the master of Chartres. Those who attempt to present Bernard's work as essentially in the Christian tradition fail to understand its peculiar nature just as much as previous scholars did when they laid stress on its unchristian character. The distinctive feature of this work consists in the use of Hermetic doctrines combined with those of Chalcidius' commentary on Plato's Timaeus and in the endeavour to incorporate them in the structure of a Christian conception of the world.

Humanist authors are represented by Leonardo Bruni of Arezzo and by Leonardo of Chios. The copy of Bruni's De militia (de Ricci 147), made shortly before 1450 , was among those used by $\mathrm{C}$. Bayley in preparing the edition of this text in War and Society in Renaissance Florence (Toronto, 1962). A small manuscript of the sixteenth century contains Leonardo of Chios' work De vera nobilitate ( $\mathrm{Bd} 96)$ in which the Greek refugee scholar, known for his report on the fall of Constantinople, criticises Poggio's concept of nobility.

Neither of these manuscripts can claim any particular distinction nor do they show any sign of humanistic script. All the more impressive are the examples of the beautiful script of the age provided by the precious documents of the Papal Chancery, hitherto unnoticed, preserved in RBD. The first is issued by Pope Eugene IV, in 1433; the second by Pope Nicholas $V$, in December 1446; the third by Pope Pius 11, in 1455; the fourth by Pope Paul II, in 1465, addressed to the Patriarch of Venice and signed by Matteo Palmieri, the Pisan humanist and author of the well-known Chronicle; the fifth by Pope Leo $X$, in 1517, addressed to Cardinal Domenico Grimani and signed in big letters by Bembo, the famous humanist; the sixth again by Leo $X$, to the Patriarch of Venice, in 1518. To these should be added an elaborately decorated document of 1489, also unlisted (found in Box III), in which Rodrigo Borgia, the later Pope Alexander VI, and other cardinals grant, in the name of Pope Innocent VIII, an indulgence of 100 days to the faithful who visit the Chapel of the Fourteen Martyrs ("Vierzehen Nothelfer vulgariter nuncupata") in the Diocese of Trent (Figure 3).

Among the neo-Latin books, the most interesting is no doubt a manuscript (Osler 7588) concerning Oxford at the time of Queen Elizabcth, written in the second half of the sixteenth century. It mainly reflects the various activities of Roger Marbeck, a prominent Oxford personality of the time. For many years a student of Christ Church and known for the elegance of his Latin style, he was appointed Public Orator for life in 1564 and, around the same time, elected Provost of Oriel. When Queen Elizabeth visited Oxford in 1566, he greeted her with a speech which she liked. On her subsequent visit, 


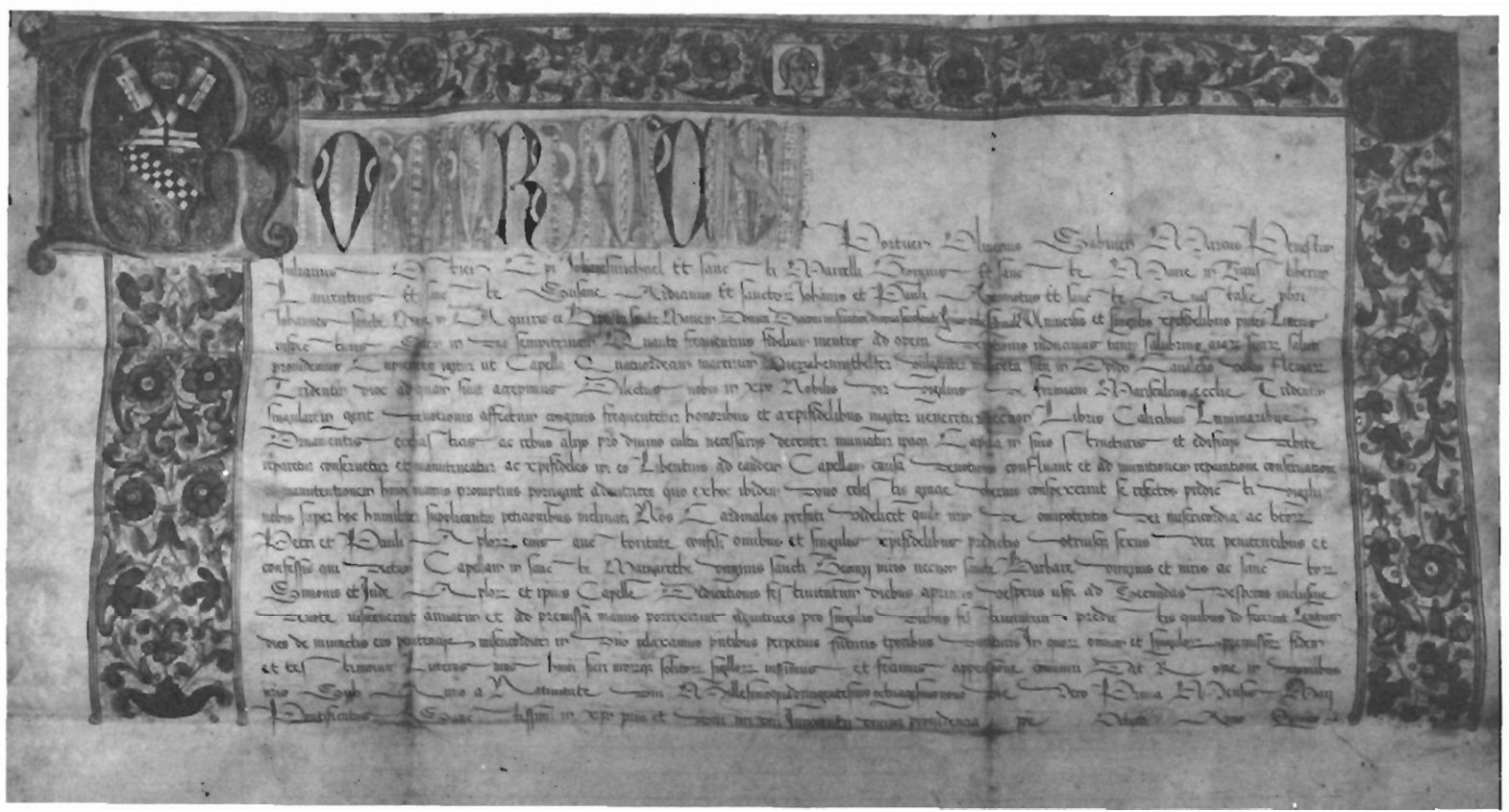

Figure 3. Indulgence of Rodrigo Borgia and fellow Cardinals, 1489.

he again delivered the Latin oration. According to the biographical sketch by W. Greenhill, "at this time, there seems to have been no more popular or distinguished member of the University; but an unhappy and discreditable marriage, which took place soon after, forced him to resign all his offices, to leave Oxford and to change the whole plan of his life." His wife died early and he decided to take up the study of medicine. A few years later, he obtained the B.M. at Oxford and the D.M. on the following day, and he became singularly successful in his new medical career. Elected Fellow of the London College of Physicians, he became its first Registrar and finally was appointed by the Queen Chief of Royal Physicians.

The Osler MS begins with a speech to Queen Elizabeth, delivered by him as Public Orator, expressing the good wishes of the University. It is followed by two strong attacks against the Roman Catholic Church, concluding with the wish that "the Roman Pope, the Antichrist, the Enemy of Peace, the Thief of human blood may be either converted or confounded." Next, there are various verses "ad Reginam Elizabetham" in which the Queen is urged in no uncertain terms to marry; for example, one under the title of
"Nube": "Quod scripsi spero, quod scripsi postulo, Nube//Sic tibi, sic nobis utilis esse potes."

There are further verses commemorating Dudley being created Earl of Leicester. This is followed by medical advice for "his patron, the Secretary of State, Sir William Cecil" and a series of verses bearing Marbeck's name and addressed to many of his friends. It can be taken for granted that the major part of the book is by Marbeck. A detailed comparison with the original manuscripts preserved in Oxford, in the Bodleian Library, would make it possible to assess what it adds to the known part of his writings.

RBD possesses some translations of, and commentaries on, Aristotle of the sixteenth century (de Ricci 130 and 131) as well as some late scholastic treatises, dated mainly from the sixteenth and the seventeenth century, on logic and on Aristotelian philosophy in general (one, entitled Aristotelicae pbilosopbiae cursus, a three-years course taught at the Congregation of the Oratory, has not yet been classified).

As to the provenance of the Latin manuscripts, a few come from Germany. The 
Albertus Magnus of the fifteenth century (Osler 7506) was owned by the Carthusians of St. Barbara in Cologne. The Sermons of Simon of Cremona (de Ricci 122) can be traced with certainty to the Charterhouse of Buxheim which was suppressed in 1803 in the wake of the changes in Southern Germany resulting from Napoleon's victory. Many of the Buxheim manuscripts are now found scattered in various libraries of Europe - such as the recently identified Cusanus codex in Berlin - and North America.

From France come several more such as the codex containing the Legenda Sanctorum (de Ricci 117) which belonged to the Cistercian College of St. Bernard in Paris. Above all, many of the illuminated initials are cut from French manuscripts

Most codices, however, come from ltaly. The Privilegia of the Carthusian Order (de Ricci 128) originated in the Carthusian Convent at Florence; Franciscus Toletanus' Commentary on Aristotle (de Ricci 131), written in Rome, was owned by the Jesuits of Florence; the Frontinus (de Ricci 139) belonged to Alessandro Francisci de Riesciis, a wealthy Florentine merchant; a treatise on canon law (de Ricci 129) belonged to an Italian Franciscan; the Ovid (de Ricci 135) can be traced to Cremona; a seventeenth-century treatise on logic (de Ricci I33) bears the bookplate of Pope Clement XI. Several others are certainly of Venetian origin. For instance, the Augustinus mentioned above (de Ricci 113) was written for a monastery in Venice; Cicero De officiis (de Ricci I37) bears the arms of the noble family Corner of Venice; the astrological manuscript described above (Osler 7513) was in the library of Domenico Grimani, the Venetian Cardinal. This is one of the comparatively few of his books that have survived, the bulk of his famous library having been destroyed by fire. The addressees of the papal documents mentioned above are all located around Venice.

Lastly, from Venice comes the surprisingly rich collection of documents issued by successive Doges of the Republic which, hitherto unnoticed, will be described in a future article dealing with the history of Italy. Mention of the statutes in Latin of the University of Ferrara and of the merchants of Florence, as well as a brief description of the many later papal documents not yet classified will also be reserved for that article.

\section{(III) Great Britain}

Well over a hundred unlisted documents, from the fourteenth to the early nineteenth century, are preserved in RBD. They all provide details concerning the social and political history of England. Among the earlier ones, three documents in Latin and French of 1385 bearing the name of William Courtenay, Archbishop of Canterbury and Papal Legate (formerly Chancellor of Oxford University) - the enemy of Wycliffe and the Lollards - merit attention.

To single out one later parchment of particular interest: an indenture signed and sealed in July 1622 by Sir Oliver Cromwell - the future Lord Protector's uncle, after whom the nephew was named - concerns the sale of some of his estates to the Earl of Buckingham. 1t points to the fact that the territorial power of the Cromwell family was declining not long before the younger Cromwell stood for Parliament. The older Oliver is referred to as "Cromwell, alias Williams." It shows that it was not forgotten that the family fortune was due to Richard Williams who had changed his name to Cromwell when he married into the family of Thomas Cromwell, the Minister of Henry VIII.

Among the documents of the same time, one of 1624 may be mentioned, concerning Robert Devereux, the third Earl of Essex, who was to achieve fame as parliamentary general. We note, furthermore, a contract between Charles I and Robert, Earl of Roxburgh, of 1634, a parchment of impressive length (88 inches) concerning the lordship of Kelso and a new enfeoffment to the earl and his heirs. The king binds himself to grant a charter under the Great Seal erecting the borough of Kelso (now a charming small town in Berwickshire) into a burgh of barony.

Three other documents also concern Charles I: the proclamation against Catholics in Scotland in 1629 (H 118), the letter to the ViceChancellor of Oxford, of 18 July 1642 (H 15), addressed to "the reverend Father in God, our right Trustee and well beloved John, Bishop of Worcester, Vice-Chancellor of our University of Oxon," and a contemporary copy of the treaty with Parliament of November 1648 , consisting of 36 folia (H 47).

Since the letter of $I 642$ points to a relationship between the University of Oxford 


\section{Hidden Treasures at McGill}

and the Government, very different from that obtaining today, the beginning may be quoted in full: "Reverend Father in God, right Trustee and well beloved: Whereas we have received a most large and ample testimony of the affection of that our University, to us, by the free loane of a very considerable summe of money in a time of very imminent necessity; These are to will and to require you to give to that our University from us our Royall Thankes, and to assure them and every one of them that this testimony of their hearts towards us shall never depart out of our Royall memory, That both they shall be carefully repayd, and the money imployed only upon the defense of our Self, the Relegion and Lawes established in this our Kingdome...Given at our Court at Beverley, the Eighteenth day of July 1642.'

Among the documents which, while bearing an RBD shelfmark, have been scantily described, we confine ourselves to singling out the following:

First, a late fifteenth - or early sixteenth century manuscript (MS 177), mixing magic formulae and prayers, written in a quaint script, which requires a thorough examination. Secondly, a late copy of the letter of Sir Francis Walsingham and "Mr. Secretary Davison" to "Sir Amice Poulet" (that is Amias Paulet) "concerning the Queen of Scots together with Sir. A. Poulet's Answer to the sayd letter, dated February 2nd 1586." It is the letter in which Queen Elizabeth's ministers remarked that Paulet, the stern jailer of Mary Queen of Scots at Fotheringhay Castle, had not "in all this time...found out some way to shorten the (life of) that Queen, considering the great Perill she is hourly subject unto, so long as the sayd Queen shall live."

This is followed by Paulet's answer written immediately after the receipt of the request conveyed by the Queen's ministers, in which he categorically refuses to comply. "My goods, living and life are at her Majesty's disposition and I am ready to loose them this next morrow, if it shall so please her, acknowledging that I hold them as of her meer [sic] and most gracious favour, and do not desire to enjoy them without her Highness good liking: But God forbid that I should make soe foul a shipwreck of my Conscience, or leave soe great a blott on my poor Posterity, to shed Blood without Law or

\section{Warrant."}

The ministers' letter was followed by the injunction that "it be committed to the Fire; such measure shall be likewise meted to your Answer, after it has been communicated to her Majesty for her satisfaction." This request regarding the letters was repeated twice, two days later by "Mr. Secretary Davison": "I pray you lett me hear what you have done with my letters, because they are not fitt to be kept, that I may satisfy her Majesty therein, who might otherwise take offence thereat."

As is manifest from the copies extant, these entreaties did not prevent this correspondence from being preserved. The RBD copy contains the following story: "This was found among Sir Amice Poulet's papers, now in the hands of one of his Descendants: it was given me by the Bishop of Ely, who had it from his Chaplain, Mr. George Harbin. June the 28th 1697. There is Secretary Davison's Apologie for himself; it seems to have taken wett, and is deficient at the beginning, some words being torne or woren out."

Apart from the documents concerning Charles I mentioned above, a lengthy Plea for Toleration of Recusants (H 1 17) and a petition of Recusants to Charles II (H 1 19) deserve to be noted among the papers belonging to the seventeenth century. The letter paints a sad picture of the petitioners' plight.

Among eighteenth-century documents special mention should be made of a manuscript (MS 77), begun in June 1730 , signed by Philip Burton, pointing to a certain Pythagorean and Platonic tradition quite uncommon at the time: "Pythagoras, his Monad and Triad or Plato's universal Soul in motion or his harmonicall problem uniting the same and th'other together or his blending an Ens and the non Entity in unity with each other.'

In spite of this fanciful title, based on the Timaeus and on Neoplatonic writings, the author is able to state his case in comparatively clear language: "Plato established this incontestable maxim that whatsoever is good is beautiful, and that goodness consists in proportionate measure, and from just proportion having beauty, health and virtue; as deformity, diseases and vices are produced by the contrary. First principles infused by 
education sway very much our tender years either to virtue or vice but the Gods have given Men the liberty of choosing good and evil, and that all virtues and vicious actions at some certain time are purely voluntary (notwithstanding Aristotle's aligations [sic] against Plato); yet it assuredly was Plato's opinion (by examining him throughout) that God had given to Men all that light that is necessary to direct them to obey the law of nature which he has engraved within their hearts, and to inform them of certain fundamental truths which enlighten the universe like so many torches; but men have despised these helps."

The volume bears the bookplate of "Philip Burton, Exchequer Office, Lincolns Inn,' known as an author of books on the Exchequer published in 1770 and later. Whether the author is identical with the 'Platonist' who began writing 40 years earlier or, more likely, a son of the same name, is unknown. At any rate, the manuscript contains several other pieces pointing to the versatility of the writer. They may well belong to different stages of his life. "A Comical History of the State and Empire of the Moon" is found in the same book as the author's reflexions about the science of perspective and his theory of space and time. A fuller description would require a separate article.

A very different mentality is apparent in an autograph letter by William Warburton dated April 25, 1763. Early in his literary career he had gained prestige because he was close to Alexander Pope; he soon became the fiercest controversalist of the age. He published many books on learned subjects directing his attacks against a wide variety of writers such as Bolingbroke, Wesley and David Hume. For hardly any other contemporary author does Hume, usually restrained and mild, in his autobiography show such dislike and contempt as for "Dr. Warburton's Railing'" and for "the illiberal Petulance, Arrogance and Scurrility which distinguishes the Warburtonian School." In this letter, which Warburton writes as Bishop of Gloucester (1759 to 1779), he remains true to his reputation as a blustering churchman, denouncing "the present scandalous ferment in the County of Gloucester" and indirectly criticising his fellow bishops. At the same time he shows himself to be a caring husband.

A different spirit animates the letter (in the autograph letter collection) from John Wesley dated February 2, 1787, to W. Black of Halifax, Nova Scotia, in which he comments on the extraordinarily difficult conditions besetting a clergyman in Newfoundland.

There are two orders for payment and three letters from the period 1788 to 1816 by Henry Fuseli (1741-1825), (the well-known painter and engraver from Zurich, Johann Heinrich Fuessli), who as a young man had been brought to England, translated Winckelmann's Painting and Sculptures of the Greeks and became a friend of Sir Joshua Reynolds. The letters contain some technical details and the recommendation of an engraver. Though of little importance, they are mentioned since they are missing in the recent edition of the Collected English Letters of Henry Fuseli. ${ }^{15}$

Among the numerous unlisted indentures which found their way into the McGill collection, there are surprisingly some that bear the seals of Oxford Colleges: Magdalen, St. John's, Corpus Christi and the present writer's own college of Oriel.

Some of the literary documents - such as those relating to the Burney family and to Coleridge - are familar to scholars. Many others, however, remain to be collated and deserve to be better known.

Letters of Hannah More and her sisters, dating from 1772 to I823, interleaved in a copy of Florio, a Tale for Fine Gentlemen and Fine Ladies; and The Bas Bleu, a Conversation, (London, 1786) (MS 125), and five others by Hannah More, found in a separate envelope, have not yet received sufficient attention. Martha More describes an evening with David Garrick in 1773; and an account of the circumstances surrouncling Garrick's death is contained in Sarah's letter of February 1779

Of special interest are the five big volumes containing A Tour of Italy, Germany and Switzerland in 1796 and 1797 by James Forbes (MS 276) in which the well-educated author, who was related to the Earl of Grannard, and who had many years of service in India, gives a detailed description of his experiences during his travels from North Germany to Rome. Written "for the amusement of a beloved 
daughter," it is full of invaluable information about German cities and prominent people he met, such as Klopstock at Flottbeck near Hamburg and Eschenburg in Brunswick. Of particular relevance is his account of Venice, since he was the last foreigner to visit it in the last days of the Republic before it surrendered to Napoleon's army. Through her marriage to the Comte de Montalembert, a French refugee in London, his "beloved daughter" became the mother of Charles Forbes de Tryon Comte de Montalembert, the well-known Catholic politician and author of Les moines d'Occident. No use has so far been made of $A$ Tour of Italy.... A selection of those parts of the journal which are of general interest is being prepared for publication by the present writer.

Autograph letters by statesmen of the late eighteenth and early nineteenth century - the younger Pitt, Palmerston, Peel, and Lord John Russell - are, on the whole, mostly of personal rather than of political interest. In 1825 Palmerston writes as a London town planner, expressing his opinion on the approach to Craven street from Pall Mall; in 1835, he speaks about the improvement of commercial relations with Spain and Portugal and his desire to see the Carlists ousted.

In an album of letters (MS 24) addressed to him as Principal of the University of Glasgow (1823 to 1856), Dr. Duncan Macfarlane preserved, together with an early photograph of the University, a letter of Sir Robert Peel dated December 1836, in which as Lord Rector he asks whether he should appear in the academic dress of the University "of which I am a member... and I am only desirous of doing that which may be most regular and respectful."'

More substantial are the papers of the Duke of Wellington from various periods of his life, bearing both on his career as military leader and as statesman. More impressive still is the important collection of several hundred manuscripts of Wellington's younger friend, Henry Hardinge (MS 180), who was to become Governor General of India and Wellington's successor as Commander-in-Chief of the armed forces. Both these collections are accessible through finding-aids in RBD.

Among the numerous nineteenth-century writers represented in the RBD collection suffice it to mention Walter Scott and Robert Southey
(Bd 113, Bd Box VI). Many of these autographs have been published, such as a humorous letter by Thackeray to Dunlop, his American friend, and two letters by Tennyson. Three other letters by Tennyson which include a long detailed comment on his poetry will no doubt be included in later volumes of the edition of his correspondence by Cecil Y. Lang and Edgar F. Shannon, Jr. ${ }^{16}$

The series of letters by Thomas Carlyle in RBD is now published in The Collected Letters of Thomas and Jane Welsh Carlyle. ${ }^{17}$ In a letter of 1831 , he praises the Westminster Review for "one quality which ought to cover a multitude of errors, and is in these days among the rarest: namely a total uncompromising contempt of Cant and Dilettantism, in all shapes; a resolution to speak the Truth so far as it is seen into and can be spoken; a feeling that the Truth is infinitely precious and alone worthy of being spoken."'18

There are also manuscripts and correspondence of Ruskin (MSS 57, 112, 180, 197), and a few letters by A.C. Swinburne to Watts of some interest, as well as two from Robert Louis Stevenson.

In a letter of 1882 , shortly before his death, Dante Gabriel Rossetti explains the meaning of one of his poems: "The trifle of mine called 'Chimes' pretends to no more than it achieves, i.e., a rather suggestive jingle in the nature of a set of refrains." A succinct autobiographical sketch by his sister Christina Georgina is contained in one of the three letters in her hand.

Among the papers of later authors, those by W.B. Yeats merit special attention. They contain typescript copies of 22 letters from 1893 to 1916, dealing with 1rish literature and addressed to the poet Catherine Tynan, whose daughter donated them to McGill. In one of the autograph letters in which the iniquity of writing for an English audience is discussed, Yeats states: "As long as the Irish public knows nothing of literature, Irish writers must be content to write for countries that know nothing of Ireland."

The collection also comprises correspondence from Kipling, his wife and his father to Lockwood de Forest and his wife Metha, two drawings by Kipling and the manuscript of Traffics and Discoveries, which contain 184 closely written pages in his small 
handwriting (MS 201), "given to McGill University by Rudyard Kipling (Doctor of Laws), 1927."

The Church is represented by two closely argued statements by Pusey, one dealing with the question of whether God was known to the Patriarchs "by the full meaning of His Name," the other commenting on "a most uncomfortable letter" he had received from "the Bishop of E." reproaching him with a "grave irregularity" in exercising his functions. Among the eight notes of Cardinal Newman, one, of 1864, expresses great concern that his correspondent, a noble woman, had placed herself under the direction of Anglican clergymen. Another letter addressed to an officer of the Bodleian Library, $\mathrm{H}$. Bliss, is evidence of his interest in certain aspects of mediacval philosophy: as late as 1873 , he asks which work the library possesses of "John Bacon, the Carmelite," that is Baconthorpe, the "Doctor Resolutus.'

Yet far more important than all the foregoing is the collection of documents concerning David Hume:

Shortly after my first arrival in Montreal, in December 1946, I noticed in a cupboard of the Faculty Club of McGill nine volumes in a neat eighteenth-century binding, each with Hume's bookplate, containing the Olivetus edition of Cicero's works (Paris 1740-1741). Any student of Hume's ethics and of his approach to religion is well aware of the attraction which Cicero had for the philosopher from his early days. In a letter to Francis Hutcheson, the philosopher, written before the publication of Book III ( $O f$ Morals) of $A$ Treatise of Human Nature, he describes himself as "great admirer of Cicero." For an important doctrine of the Treatise, making the virtue of an action dependent on the goodness or badness of the motive, he adduces the authority of De finibus bonorum et malorum; and of De officiis he states, "I had indeed the Book in my Eye in all my Reasonings." His thorough knowledge of Cicero's orations is brought out in a long letter to Henry Home, Lord Kames.

How much Hume liked his "Olivet's Cicero" 19 (in the index of the Oxford edition of The Letters of David Hume wrongly described as "Olivet's Virgil"), now at McGill, may be gathered from the fact that he had sent one volume to his publisher William Strahan, asking him to take it as a model for the new edition of his Essays and Treatises, to serve as a forerunnner to a similar edition of his History. He adds "Let us see a Sample of your English Press: I do not believe you can make such a Book; and I give you a Defiance. Pray return the Book carefully, after you have carefully survey'd it." In a following letter, he inquires whether he may pretend "to rival Cicero in Garb and Accoutrements." Hume's marks in the volumes containing the philosophical writings show which parts were of particular interest to him. They also indicate that he continued to read Cicero after the completion of the Treatise.

The unexpected find gave rise to the project, favourably rcceived by the authorities in charge of the Library, of forming a collection of original source material which would provide the basis for an intensive study of Hume's life and thought. Thanks to the helpful cooperation of Mr. Richard Pennington, University Librarian until 1965 , a collection was built up which, in many respects, is surpassed only by those in Edinburgh and London. It contains no fewer than 50 letters in Hume's own hand, more than those possessed by any other single library in North America; some have been published in our edition of New Letters of David Hume; ${ }^{20}$ others will appear in the edition now being prepared.

Of particular importance are the 37 letters from Hume to the Comtesse de Boufflers, the lady who, from 1761 until his death in 1776 , occupied a special place in his affections (Figure 4). Her beauty and wit, combined with her status as mistress of the King's cousin, the Prince de Conti, as whose official hostess she acted at his Paris residence, the Temple, gave her a prominent place in Paris society. She was admired by Rousseau and other writers. Horace Walpole sums her up with his usual malice: "She is two women, the upper and the lower. I need not tell you that the lower is galante and still has pretensions. The upper is very sensible, too, and has a measured eloquence that is just and pleasing - but all is spoiled by unrelaxed attention to applause." 21 The self-reflection attributed to her and reported by Sainte-Beuve is more concise: "Je veux rendre à la vertu par mes paroles ce que je lui ôte par mes actions. " 22

Wherever she went, she attracted attention. At the time Hume frequented her in Paris, she 
was known as "l'îdôle du Temple." Later in life, as a French historian delicately puts it, "quand la passion de l'esprit succéda chez elle aux passions d'un âge plus tendre," she was also called "la Minerve savante."

She carefully kept Hume's letters, together with the eleven which she received from Rousseau - among which was one of his most dramatic - and two from George Keith, the tenth Earl Marishal of Scotland (Governor of Neuchâtel under Frederic the Great), who was Hume's friend and Rousseau's patron. Now bound in dark blue morocco, the volume (MS 4) contains, moreover, copies in Madame de Boufflers' own hand of two letters she sent in July 1766, one to Hume and one to Rousseau, in which she expressed her feelings on the quarrel between her two friends. (These copies were obviously made and kept due to the particular importance of the matter.)

How to account for the fact that so many precious documents written by different persons are united in one and the same volume, together with five letters from Hume to the Marquise de Barbentane? The question may be answered with certainty by tracing the history of the book. 1t is linked with the sad fate, to which Hume scholars have paid no attention, which befell Madame de Boufflers in her later life. During the Revolution, she retired with her daughter-in-law to a house in Auteuil. The Duchess of Lauzun, the daughter of a close friend, became a victim of the Terror. Madame de Boufflers and her daughter-in-law were imprisoned and judged by the revolutionary tribunal. Thanks to the intervention of a devoted friend who was acquainted with the powerful Foucpuier-Tinville, they escaped the Guillotine and were finally set free in October 1794. Madame de Boufflers survived until 1800 in severely reduced circumstances.

The letters from Hume, Rousseau (Figure 5) and Lord Keith which she had kept came into the hands of André-Daniel Laffon de Ladebat. This financial expert, politician and publicist (1746-1829), author of a Discours sur la nécessité et les moyens de détruire l'esclavage dans les colonies ${ }^{23}$ survived the Revolution but, as a strong critic of the Directoire, was deported to Guyana. At the end of the century, he returned to France. As he had done before, he collected documents of historical and literary interest at public auctions. When the Hume and Rousseau papers came into his possession, he decided to publish them. At first, he meant to do this in Paris, but then preferred to take them to London where he went in 1815 to retrieve what remained of the money which he had deposited there after the Peace of Amiens. In the end, he seems to have found it more profitable to sell the precious volume, together with some other contemporary letters relating to Hume and his friends. They were all published in London a few years later, with many changes in spelling and punctuation, by an unnamed editor who had acquired them, under the title of Private Correspondence with Several Distinguished Persons between the Years 1761 and 1776 now First Publisbed from the Originals. ${ }^{24}$

The text was reproduced without changes in J.Y.T. Greig's edition of Hume's Letters. The McGill manuscript, in the edition now being prepared for publication, will, for the first time, make Hume's original text available. Once these letters at McGill arc published, they, together with the 39 letters from Madame de Boufflers to Hume which are preserved among the manuscripts of the Royal Society of Edinburgh (now deposited at the National Library of Scotland), will make it possible to follow step by step the development of a relationship which clearly was of great importance to both correspondents.

In one of these letters, for instance, written five months after he left France, Hume expresses the hope that he might return and join her on a voyage which would lead them to Italy and Greece. "What do you think of the project? The idea is not altogether extravagant. Might we not settle in some Greek island, and breathe the air of Homer, or Sappho, or Anacreon..." Whether Hume really intended to do so, may well be doubted. In any case, they never saw each other again.

In the succeeding years, letters became far less frequent. Was this merely duc, as has been generally assumed, to a cooling of affections resulting from years of separation without the likelihood of meeting again? New documents, in the form of personal letters, reveal that Madame de Boufflers' attention was directed towards a new correspondent, the King of Sweden. All the more striking is the last letter which Hume, knowing that his death was imminent - he died 


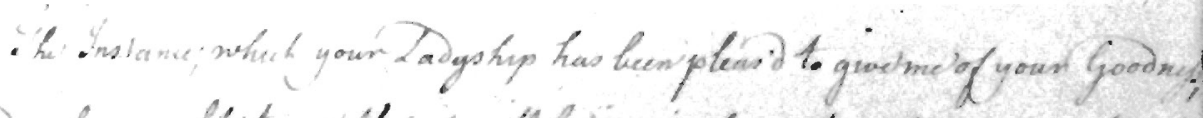

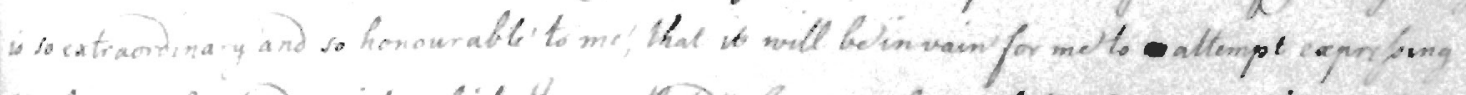

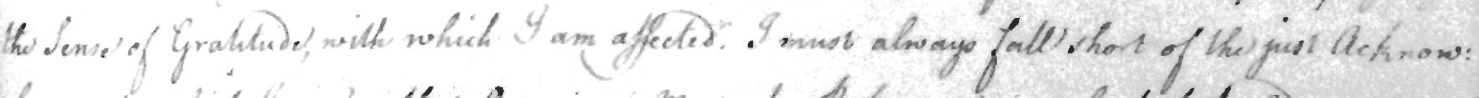

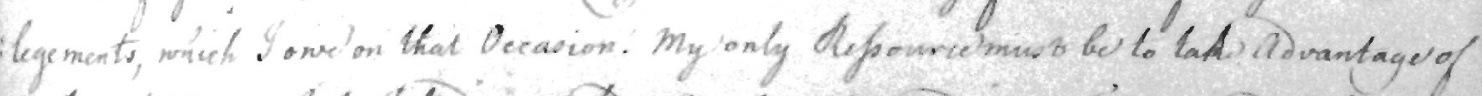

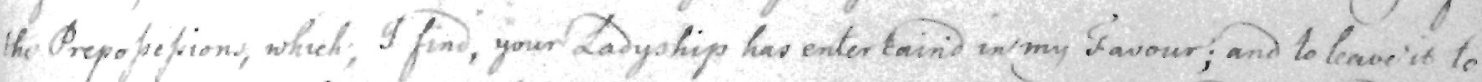

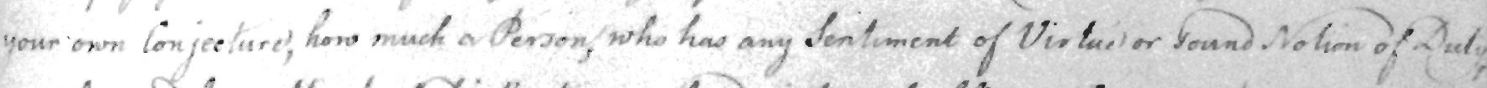

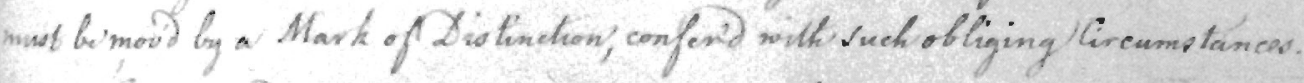

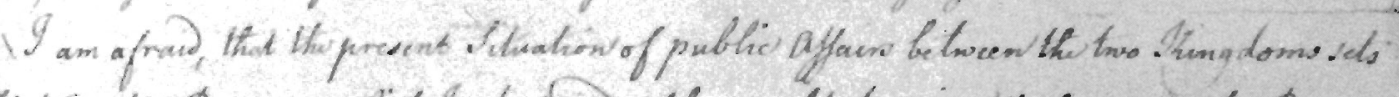
at a Distance' the Prapuet, whel Ienter taine, of being able to conjoy the Company of a Derson, -o celbrate for her Accomptishments by all who havi any Imonilege' of the Court of t nance.

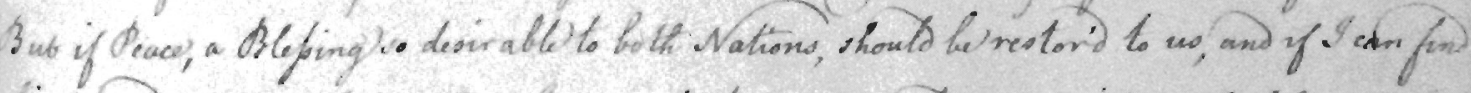

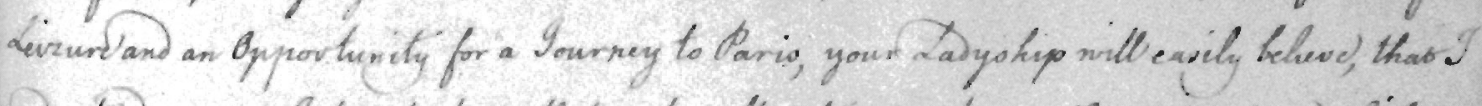
understan my onom Interesto too well hot to cultwat every day an Alequaintaince, which mus.

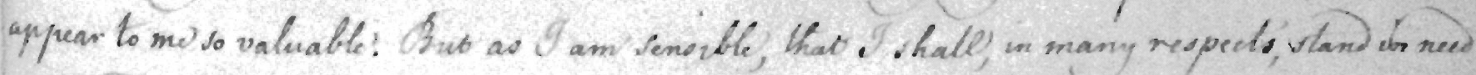

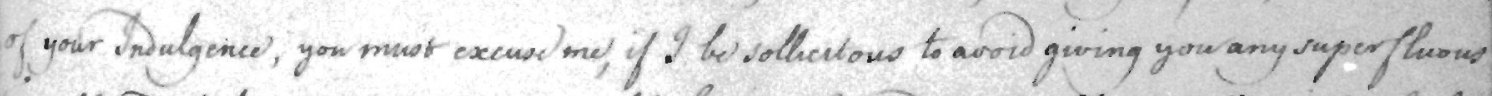

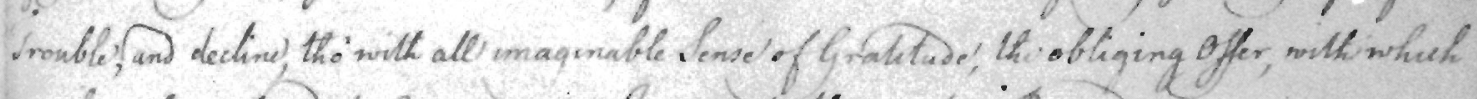
you have brem pleav to honoun me. I am, with the greativi Cregard.
Loidons?
$2 \operatorname{sep} \operatorname{tr} 1>6,1]$
Madam
Youm an y ríno
conart
A avid Tlume.

Figure 4. Letter of David Hume to Mme. de Boufflers, 2 September 1761 (MS 4). 
five days later - wrote to her to comment on the death of the Prince de Conti, her long-time lover. "Tho' I am certainly within a few weeks, dear Madam, and perhaps within a few days, of my own death, I could not forbear being struck with the death of the Prince de Conti - so great a loss in every particular. My reflection carried me immediately to your situation in this melancholy incident. What a difference to you in your whole plan of life!..."25

"Surely," in the words of Sainte-Beuve, "the woman who inspired a dying sage with such supreme sentiments of concern and friendship was not an ordinary soul, and this document alone that links her with one of the most beautiful deaths that philosophy offers us would suffice to prevent her name from dying." 26 For some unknown reason, the letter was not included in de Ladebat's collection. The text in Greig's edition of The Letters of David Hume, is based on earlier printed sources and disregards the facsimile available in the Lennox collection of the New York Public Library. Detached from the other letters, the original passed through the hands of a succession of private collectors. It was an unexpected thrill to find it in Harvard University Library which in 1972 had acquired it (b MS Am 1899(93)), together with an unpublished letter. In Madame de Boufflers' own hand, it bears after the date on top of the address, the inscription "pour mannoncer [sic] sa mort prochaine."

After having served the editor of Private Correspondence, the Ladebat volume was in due course acquired by one of the most prominent British autograph collectors, Alfred Morrison, in whose sumptuous catalogue it is described. After the sale of his library, it came into the possession of an American collector, Lucius Wilmerding. Finally, when his collection was sold, it was possible to secure the volume for McGill.

As a result of a systematic search, I found two additional volumes in the stacks of the McGill Library: Hume's copy of Theophrast's Characters (Lyon 1612) and his Anacreon together with some poems by Sappho and Theocritus (London 1695). The latter may well be the book which he had in mind when suggesting to Madame de Boufflers in the letter quoted above that they should "settle in some Greek island and breathe the air of Homer, Sappho, and Anacreon, in tranquility and great opulence." In a New York bookshop I noticed two other volumes belonging to Hume, the Abbé de Mably's Observations sur l'histoire de France (Geneva 1765); they were acquired for McGill in 1951.

The Hume collection remains to be described in detail. It has lately been enriched by a precious volume, acquired at the initiative of Professor David Norton, which once belonged to Hume and formed part of the library of his favorite nephew, the lawyer David Hume (later Baron Hume). It contains a collection of pamphlets, occasioned by the performance in Edinburgh, in the year 1757, of Douglás, the play by Hume's friend, John Home. Several of these pamphlets contain strong attacks by the hard-line presbyterian clergy and its sympathisers against David Hume, branded as "the Infidel." "..We see, by the growth of Infidelity, the fatal effects of thus permitting David and John Home to go on after the manner they do without being censured."

The autograph collection of RBD also contains a letter of four pages described as "not by the philosopher." It is in fact in the hand of Hume's nephew, David, written by him in May 1809 to Lord Melville, expressing his wish for a seat on the bench of the Court of Exchequer, "and if that object could not be attained, my desire to exchange my Sheriffship (which I have now held for 26 years) for some more beneficial situation."

\section{(IV) Canada}

No systematic survey of the collection of Canadiana has yet been attempted. It is to be hoped that sufficient means may soon be obtained to provide a detailed description of the material preserved in the $\mathrm{RBD}$, the McCord Museum and other McGill libraries and thus to make this important source of Canadian history generally available. It is known so far only by a brief and insufficient list in the Canadian Historical Review, ${ }^{27}$ and information contained in A Guide to Archival Resources at McGill University.

Particularly numerous are the administrative and personal papers concerning French Canada; two documents, for example, one of the seventeenth century, confirming a grant of land at Trois-Rivières by the Compagnie de la Nouvelle France to François de Champfleur, the 


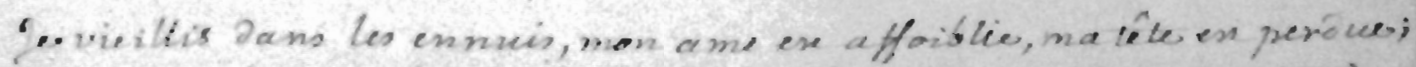

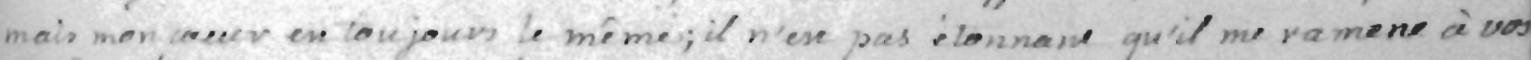

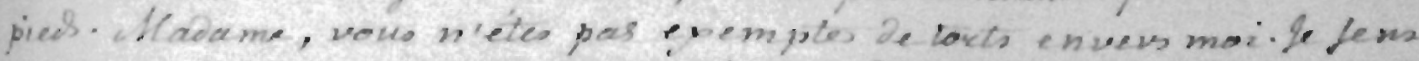

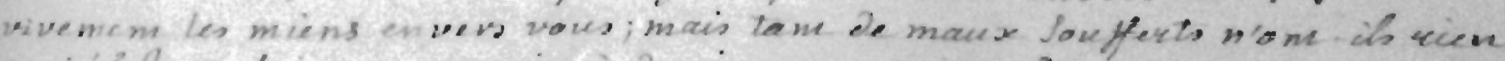

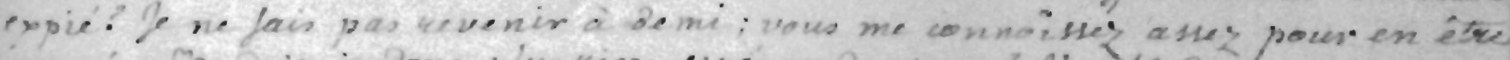

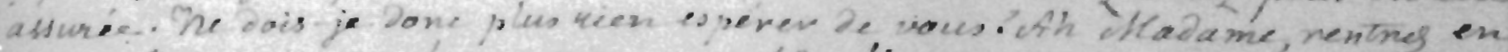

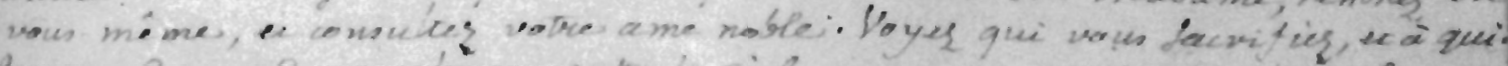

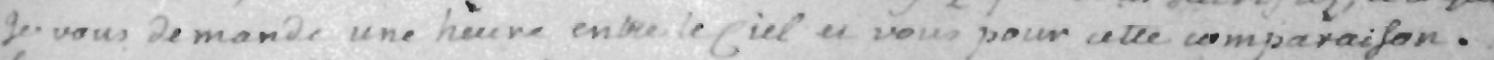

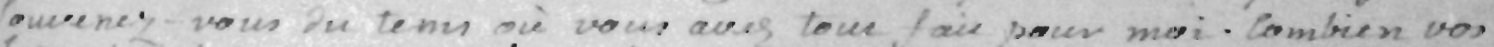

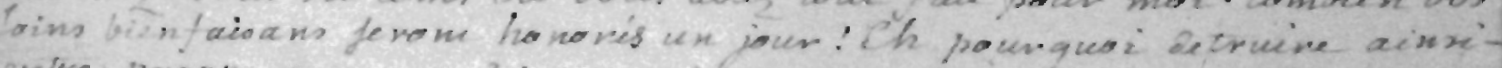

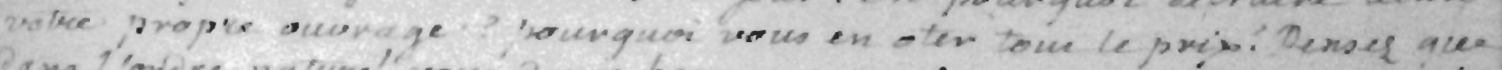

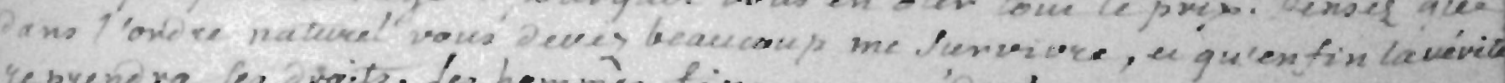

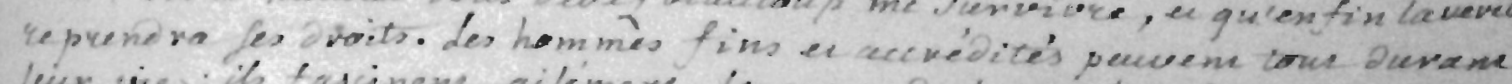

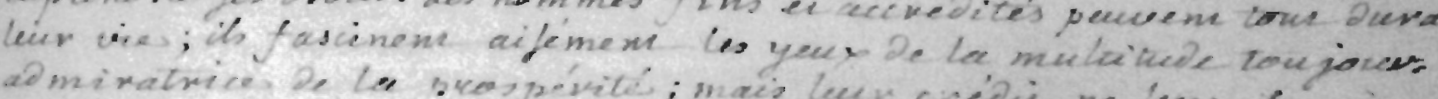

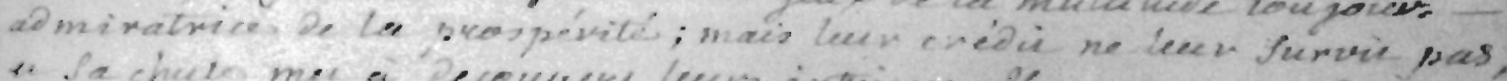

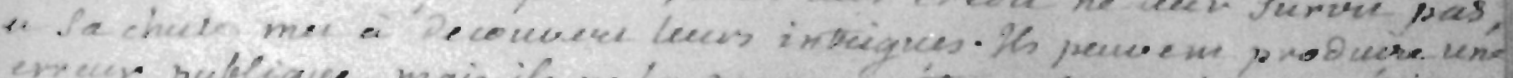

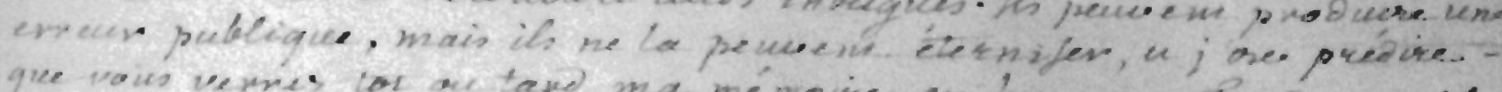

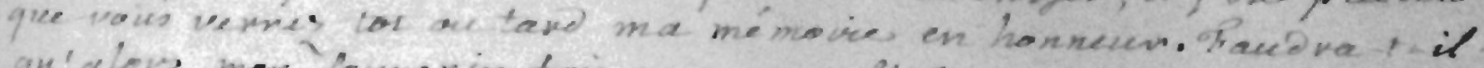

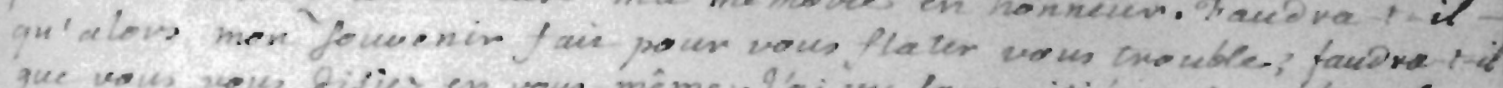

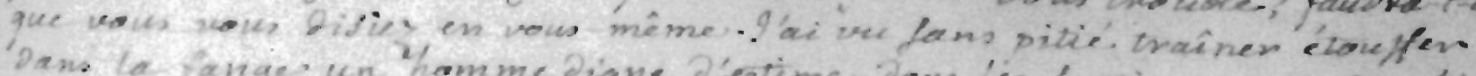

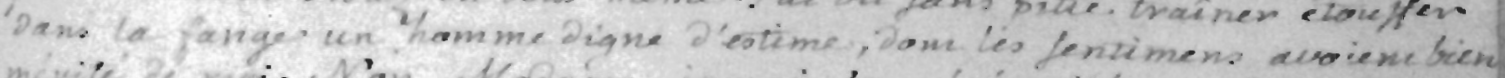

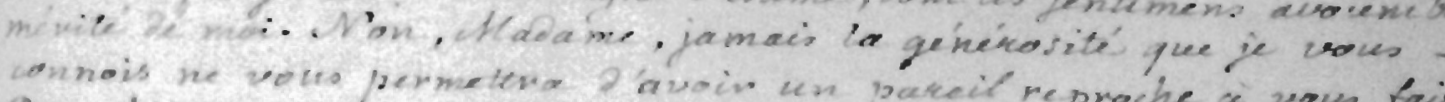

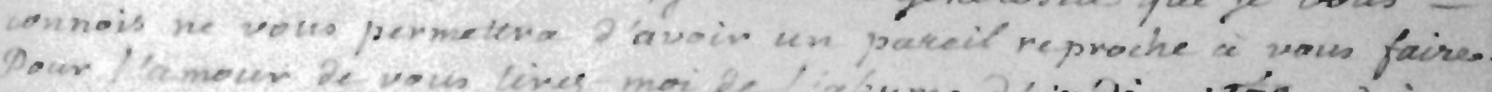

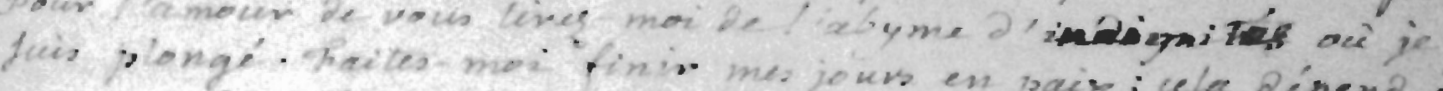

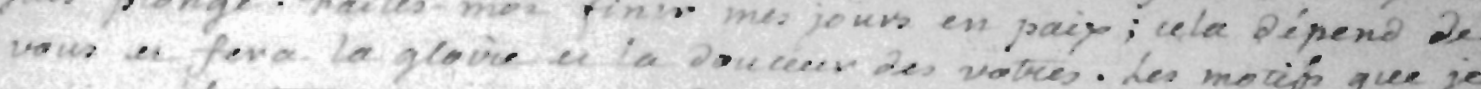

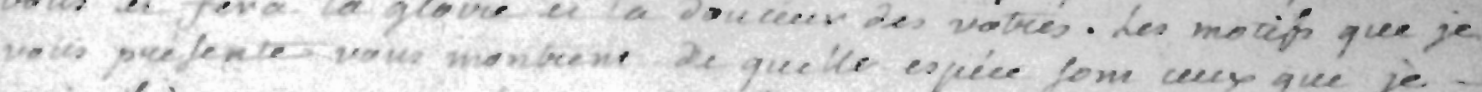

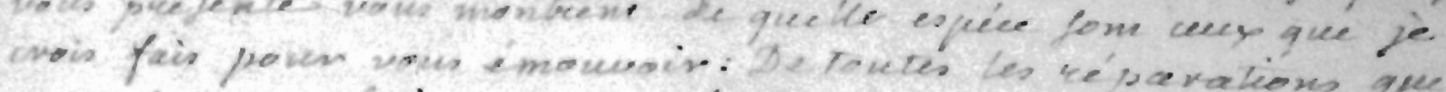

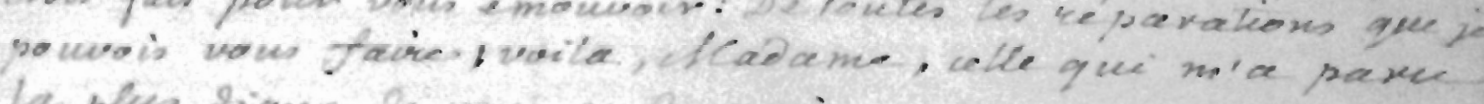

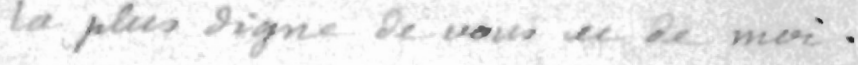

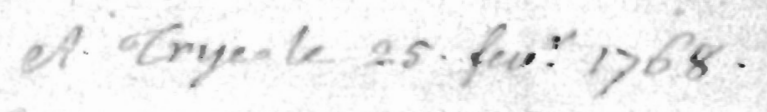

Figure 5. Letter of Jean-Jacques Rousseau to Mme. de Boufflers, 25 février 1768. (MS 4). 
other, a copy of a grant of land to Jean Godefroid natif Lanctot, in 1633.

Of special interest are the papers relating to individual families such as Rigaud de Vaudreuil, I.efebvre de Bellefeuille, Lemoyne de Longeuil, Lambert Dumont, Boucher de Niverville, Hertel, de Saint-Ours, Le Ber de Senneville and, by far the most numerous, those of the Chartier de Lotbinière family (which include a copy of a letter from Michel, Marquis de Lotbinièrc, to Benjamin Franklin), as well as those mentioned in the preceeding paragraph. These papers and many others containing grants of land and legal documents from the first part of the seventeenth century onward, formed part of the collection of Archibald Chaussegros de Léry Macdonald, which was acquired by McGill in 1922; it now bears the signature MS 439. A handwritten finding-aid completed in 1987 by Alexander Wright and Dr. Richard Virr provicles detailed information.

A significant piece illustrating the arbitrary nature of punishment under the Ancien Régime is a letter (H43) dated 15 September 1729 , signed at Versailles by the comte de Maurepas (then in charge of the naval establishment), condemning Captain Jean Baptiste Paul, accused of barratry (gross neglect of his duties). In the absence of witnesses and sufficient proof, no trial was held. Instead, "for the public good" he was - without legal procedure - condemned to being deported. The punishment consisted of his being sent to Canada, forced to serve as a simple sailor on boats plying between Quebec and Montreal, not being permitted ever to return.

A thorough listing is needed of the many military papers in the McCord Museum of Canadian History and in RBD concerning the British conquest of Canada and the War of the American Revolution. To these should be added, on the French side, a letter (in the Lawrence Lande Collection of Canadiana), written in 1759 by the Marquis de Montcalm from his headquarter at Beauport, less than two months before his death, to an unnamed addressee in whom he obviously had confidence (and whom Lande assumes to be Antoine de Bougainville, his aide-de-camp), criticizing the performance of his senior officers, including de Ramezay, about whom unflattering remarks are made: "M. de Ramezay ne donne aucun ordre et ne décide rien. ...Je pars dans le moment leur dire que ce sont des fous, et ils en pensent peut-être autant de moi..."

Montcalm's signature appears, too, together with those of many other prominent personalities of the French colony, on two marriage contracts in the Lande Collection, each clated 1759 , one of which is between a French officer, stationed at Montreal, and the daughter of an officer's family in the same town. ${ }^{28}$

On the British side, there are for instance the papers of General Wolfe and of his successor as commander, James Murray, the first military governor of Quebec and subsequently the first civil governor of the newly conquered territory. (Two of Murray's brothers, Lord Elibank and Alexander Murray, were correspondents of David Hume; James Murray was acquainted with him.)

For the later period there is, also in the McCord Museum, the correspondence of Friedrich Adolf Riedesel, Baron Eisenbach, who arrived in Quebec in 1776 as commander of the German corps of over 4200 men, sent by the Duke of Brunswick-Wolfenbüttel. Of no less interest are the documents in the McCord Museum regarding the War of 1812-1815 between the United States and the joint forces of Britain and the Canadian militia. Moreover, numerous papers are found there, illustrating later periods of political, military and intellectual history.

To mention only one example of a document (in RBD, unnumbered) bearing on civil administration, which has escaped notice in any of the existing lists, a writ, "allowed on $30 \mathrm{July}$ 1800 " begins as follows: "George the Third by the grace of God of Great Britain, France and Ireland, King, Defender of the faith, and so forth. To the Keepers of our Peace, and to our Justices assigned to hear and determine divers felonies, trespasses and other mis-demeanors done and committed within our District of Montreal, and to every of them, Greeting. " It refers to a document concerning "the City and Parish of Montreal" entitled "Procès verbal du chemin de la division de St. Michel." Witnessed by James Monk, "our Chief Justice of our said Court of Kings Bench, at Montreal," it is signed by James McGill, the future founding father of the University, in his capacity as Justice of the Peace, and it bears the signature of several prominent Montreal citizens, of both French and 
Hidden Treasures at McGill

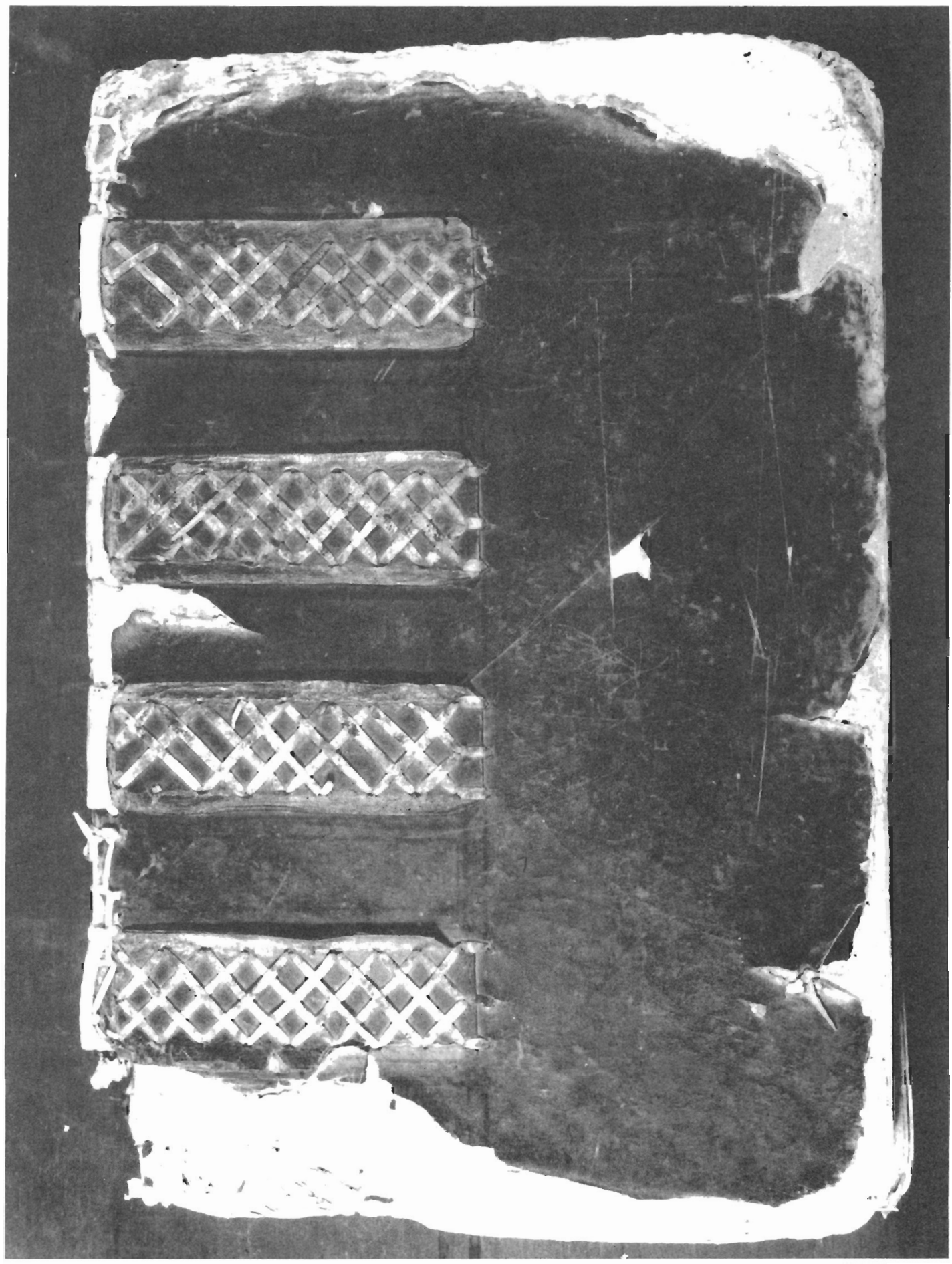

Figure 6. Pierre-Luc Du Jaunay, “Dictionarium Gallico-Outawaki," 1740-48 (MS 281). 


\section{Hidden Treasures at McGill}

British origin, among whom are the Hon. Pierre Louis Panet and two women, Soeur Marie Noreau and Soeur Benoite Ceras.

A document of particular significance for the relations between French missionaries and Indians in the Upper Lake districts is the "Dictionarium Gallico-Outawaki" (MS 281), a huge volume of $58 \mathrm{I}$ pages in large format (Figure 6). This dictionary of the language of the Ottawa Indians was compiled by the Jesuit missionary Pierre-Luc Du Jaunay who had lived in their midst since 1735. He started work on his dictionary in 1740 and completed it eight years later. It is characterized by the fact that for each French word he provides a lengthy list of Indian equivalents according to the context of its use and that he pays special attention to metaphorical meaning, e.g., "Il a de beaux yeux" - "il a l'air ouvert et riant." But this is followed by "Je luy arrache les yeux."

Before sailing for Canada (in 1734), the author had studied theology at the Royal College of La Flèche at which Descartes had received his early training. His high intellectual standing is evident. At the end of his impressive work the author states: "I have completed a monument more fragile than glass and lighter than a flying feather and flax." At the same time he appeals to the reader to add corrections ("O tu qui legis haec, corrige, corrige"). It is no surprise to read that, after the conquest, the British Commander writes that the priest was "a good man and had a great deal to say with the Savages, who will believe everything he tells them." In fact, by its careful description of the language, the dictionary provides information concerning the thought and the life of the Indian tribe. By its thoroughness and its regard for the different contexts in which words are used, it has few equals in eighteenth-century lexicography. It is an important source for the student of American Indian civilisation.

Mention should also be made of the papers regarding the history of the first Jewish family established in Canada, those concerning Aaron Hart who came to Canada in 1760 as Purveyor to the British army, settling at Trois-Rivières, as well as those of his descendants down to 1933 . The collection, in the McCord Museum and in the University Archives, forms a noteworthy supplement to the papers preserved in the Archives du Séminaire de Trois-Rivières.
While there are many Canadian literary figures represented in the McGill collections, suffice it to single out the numerous literary manuscripts and letters of Stephen Leacock which are preserved in RBD. Nor should it be forgotten that among the papers of prominent contemporary authors, RBD preserves some of the correspondence and manuscripts by Hugh McLennan, until recently associated with McGill.

Mention of the rich material bearing on such items as the early fur trade, the development of retail trade in Montreal since 1846 (papers of the Morgan family) and of the history of the Montreal Stock Exchange is made in $A$ Guide to Archival Resources at McGill University.

Special attention is due to the vast collection of documents by William Douw Lighthall (1857-1954) covering his manifold activities as author and founder of various municipal and national organisations. The detailed inventory prepared by Dr. Richard Virr will at last make it possible to exploit this important source of local and national history during the second half of the nineteenth and the first half of the twentieth century.

\section{(V) History of Science}

As founder of the Canadian Society for the History and Philosophy of Science, the author of this brief survey would like to draw attention in a separate section to some interesting documents found in McGill collections. In so doing, medical manuscripts which are fully described in the Osler catalogue have been excluded. Our knowledge of the transmission of Greek medical science will undoubtedly be enriched when the Oriental translations of, and references to Galen and other Greek authors are made accessible.

Mediaeval science (other than astrology and alchemy) is represented by the astronomical treatise, de Ricci 134 (see above Latin Manuscripts, p. 72).

For his contribution to optics, in particular his account of refraction and the properties of concave and convex lenses, his inquiries into the mechanics of water and steam, his significant improvement to the camera obscura by adding a convex lens to the aperture, his efforts directed towards the invention of the telescope, his stress on the necessity of experimentation and his refinement of experimental techniques, as well 
as his refutation of the belief in demons and in witches, and his role in the founding of the Accademia dei Segreti in Naples (designed to reveal the secrets of nature), Giambattista Porta (1535-1614) has an assured place in the history of scientific thought. At the same time he is, apart from many bizarre speculations, known for his attempt to resuscitate the age-old doctrine of physiognomy and to establish this doctrine of the correspondence between the visible form of the body and the internal character of man on a sound 'scientific' basis. In addition to many of his books, the Osler Library possesses the original Latin manuscript (MS 7618), neatly written in his own hand, of his work on chiromancy which he considered to be an especially important part of physiognomy. It is entitled De ea naturalis fisiognomoniae parte quae ad manuum lineas spectat ("About that part of the natural physiognomy which concerns the lines of the hands"). Based on the observations he made for many years in the prisons of Naples and elsewhere, it contains a great number of drawings of hands, feet, claws, neatly executed by Porta. These drawings are lacking in the Italian translation, printed long after his death (Naples, 1677), by which this book has so far been known. After severely attacking contemporary writers on the subject, whom he labelled pseudo-scientific imposters, Porta prefaces the work with a chapter on "the dignity of the hands."

The extensive correspondence of Georgio Baglivi, the anatomist and physician of Pope Innocent XII, is preserved in the Osler Library. It contains letters to and from prominent Italian natural scientists of the latter part of the seventeenth century, such as Malpighi, Fardella, Redi, and Lorenzo Belloni. It has recently been published as The Baglivi Correspondence From the Library of Sir William Osler. ${ }^{29}$

Isaac Newton's copy of his Opticks: Or, a Treatise of the Reflexions, Refractions, Inflexions and Colours of Light. Also Two Treatises of the Species and Magnitude of Curvilinear Figures, London, 1704, (MS 46) is, together with his Tractatus de Quadratura Curvarum, preserved in RBD. The work on optics contains a substantial number of corrections and additions in his hand, for instance a long addition to the Second Book, Part IV, p.135 (Figure 7). The changes were incorporated by him in the later editions of his work.

The botanical field-notebook in Latin of Herman Boerhave, the famous Lcyden physician, contains his observations of plants from about 1711 to 1726 . The entries in his characteristically neat hand are systematically arranged with precise indication of dates and locations - whether in the dunes of Katwijk or "in sylva Hagana" or in his own garden. This notebook constitutes a summary of the flora of the Netherlands of his time. The volume (MS 229) has been acquired by the Osler Library, which also possesses (in MS BO 1118) copies of many of his letters to Italian scientists (e.g. to Morgagni), some of which are copied from the originals, the transcript being attested in 1745 by a notary of Padua. The same manuscript contains, at the beginning, an autograph letter of 1735, with Boerhave's well-known seal "Simplex veri sigillum," the device adopted by Wittgenstein.

Several works by Sir Joseph Banks are found in the Blacker-Wood Library: the original manuscripts, now published, of his field-notes in Latin to his Voyage to Newfoundland (1766), the diary of the first half of his Voyage to Iceland, 1772, and the transcript, made about 1820, of the Endeavour Journal (1768-1771), with botanical and zoological comments. Among the 900 paintings of North American wildlife in Blacker-Wood's Taylor-White collection, there are several based on Banks' specimens.

In the RBD autograph collection, William Buckland, the founder of the Oxford School of Geology, and author of Reliquiae diluvianae or observations on the organic remains attesting the action of a universal deluge, known for his attempts to confirm the Biblical account of the age of the world in the light of geological and palaeontological evidence, is represented by three letters written from Oxford between 1824 and 1836, and a "Notice to Geologists" of October 1841 . Joined to these are four letters by his son Francis, the ichthyologist, dating from the period 1858 to 1874 , the first of which contains a lengthy humorous account of his examination of a stuffed "Mermaid" which he recognised to be a "merman," "for it is a gentleman," found in a back parlour of a public house in London, "such as we read in Oliver Twist or Jack Shepherd." He knows where the corresponding mermaid is and will look her up. Two further letters by William Buckland are 


\section{[ $\mathrm{I} 35]$}

Q4. II. Do not great Bodies conferve their heat the longeft, their parts heating one another, and may not great denfe and fix'd Bodies, when heated beyond a certain degree, emit Light fo copioully, as by the emiffion and reaction of tts Light, and the reflexions and refractions of to rays within te pores to grow ftill hot ter, till it comes to a certain period of hent, fuch as is that of the Sun? And are not the Sun and fix'd Stars great Earths vehemently hot, whofe heat is conferved by the greatnefs of the Bodies, and the mutual action and reaction between them, and the Light which they emit, and whole parts are kept from fuming away, not only by their fixity, but alfo by the vaft weight and denfity of the Atmofpheres incumbent upon them, and very ftrongly compreffing them, and condenfing the va-

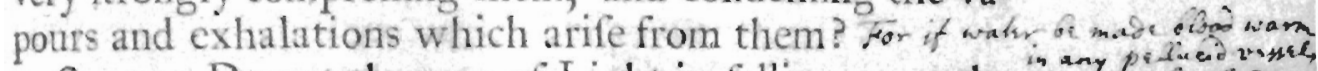

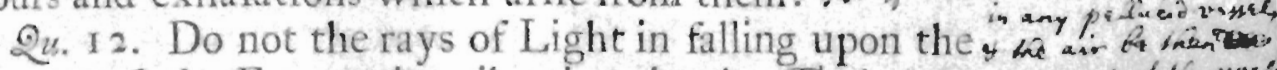
bottom of the Eye excite vibrations in the Tunica rejoram on of the rum

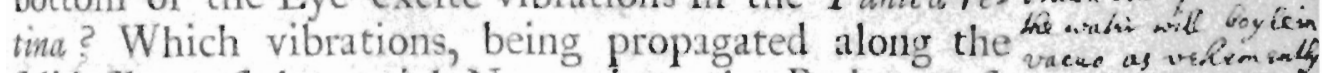
folid fibres of the optick Nerves into the Brain, caufe as at sesk siff a the fenfe of feeing. For becaufe denfe Bodies conferve mach grashr hiat their heat a long time, and the denfeft Bodies conferve is a pel curra a fir their heat the longelt, the vibrations of their parts are in wa opan air tor of a latting nature, and therefore may be propagated cumbend climesson along folid fibres of uniform denfe matter to a great di-kexps soun herapos ftance, for conveying into the Brain the impreffions $y$ aingers the wat made upon all the Organs of fenfe. For that motion from foyling hat he which can continue long in one and the fame part of a heas is ragnists tr Body, can be propagated a long way from one part to make id ooy a in another, fuppofing the Body homogeneal, fo that the vacus. An so the

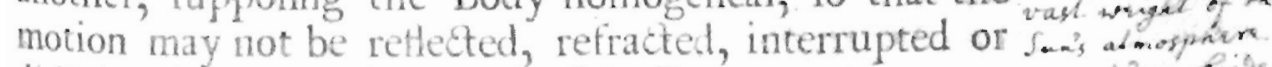
dilordered by any unevennefs of the Body.

man theri heajer

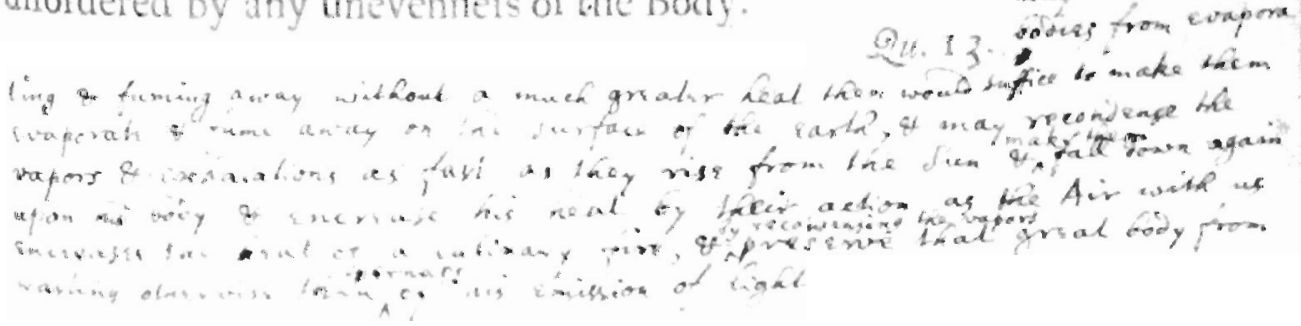

Figure 7. Isaac Newton's copy of his Opticks, 1704, with his additions (MS 46). 
found interleaved in the Babbage book described in the next paragraph.

Of particular interest for the history of science in the nineteenth century is the copy of Charles Babbage's Passages from the Life of a Philosopher, London 1864 (MS 173). This wellknown autobiography is remarkable in many ways for the idiosyncratic reflexions of the author preceded by two devices, one from Byron's Don Juan: "I am a philosopher. Confound them all - Birds, beasts and men; but no, not womankind." The second from "Autobiography of an Oyster" decipbered by the aid of photography in the shell of a philosopher of that race recently scolloped.

The book is no less remarkable for the "impression from a woodcut of a small portion of Mr. Babbage's Difference Engine" - his first computing machine "commenced in 1823" and part of the Exbibition 1862. Yet the particular value of the McGill copy consists in the wealth of handwritten letters from leading scientists of the nineteenth century, which the owner, Frederick Hendriks, a statistician and proponent of an international currency, had bound in 1893 between the leaves of the volume. Among them, there are three letters from Babbage, and one each from John Dalton, John Frederick William Herschel and Hans Christian Oersted. There are, moreover, two letters from Michel Faraday (one of them to Herschel, Figure 8) and no fewer than eleven to Faraday (one from Babbage and two from Mark Isambard Brunel). As I learned from Dr. Frank Jones, the scholar in charge of the edition of Faraday's correspondence, planned by the Royal Institution of Great Britain, the existence of these McGill letters was hitherto unknown. To do justice to the riches of its contents, it will be necessary to devote a separate article to this copy of Babbage's work.

About 3000 folders of correspondence of naturalists and 300 manuscripts ranging from the middle of the nineteenth to the early twentieth century are preserved in the Blacker-Wood Library. It is particularly rich in material concerning ornithology. Of special interest is the collection of imprints and photographs of manuscripts concerning falconry. It also contains the beautiful Feather Book, ${ }^{30}$ by Dionisio Minaggio, gardener to the Governor of Milan, which consists of 156 pictures of which 112 are of birds, while the others represent musicians, hunters and figures familiar from the Commedia dell'Arte. Each picture has been made from bird feathers pasted on heavy paper mounted on the pages of a folio volume. Since it preserves some of the oldest bird-skins known, it is an ornithological document of great importance.

An autograph letter by Louis Pasteur is preserved in the Osler Library.

Among the papers attributed in the catalogue of RBD to Raymond Poincaré, the politician and later President of the French Republic, there is one which, in fact, is written by his cousin, Henri Poincaré, the mathematician, whose importance for the philosophy and methodology of science has been more fully appreciated during the last two decades. It is a letter to an unnamed friend, concerning the Fuchsian functions. It is undated, but since the "Mémoire sur les fonctions zétafuchsiennes," 31 of 1885 is referred to, it must have been written not long after this date.

Among the documents concerning Canadian scientists of the nineteenth century those concerning geology are the most numerous. To begin with, the papers and extensive correspondence of the first director of the Geological Survey of Canada and discoverer of natural resources, William Edmond Logan (1798-1875), are preserved in the Archives and RBD.

Next comes the large collection of documents in the Archives relating to Logan's younger friend, John William Dawson (1820-1899), Principal of McGill from 1845 to 1893 , where for many years, as Logan Professor, he taught geology and palaeontology. The papers show his lifelong interest in the relation between science and religion as well as his strong criticism of Darwin. A part of his correspondence concerns his activities for the Royal Society of Canada, of which he was the first president (1882), and for learned societies in Britain and the United States. Furthermore, the Archives contain the papers and daily correspondence of his son, George Mercer Dawson, the geologist, which throw light on his survey of the Canadian West and North.

The Archives also preserve the papers of another eminent geologist, Frank Dawson Adams, J.W. Dawson's successor as Logan 


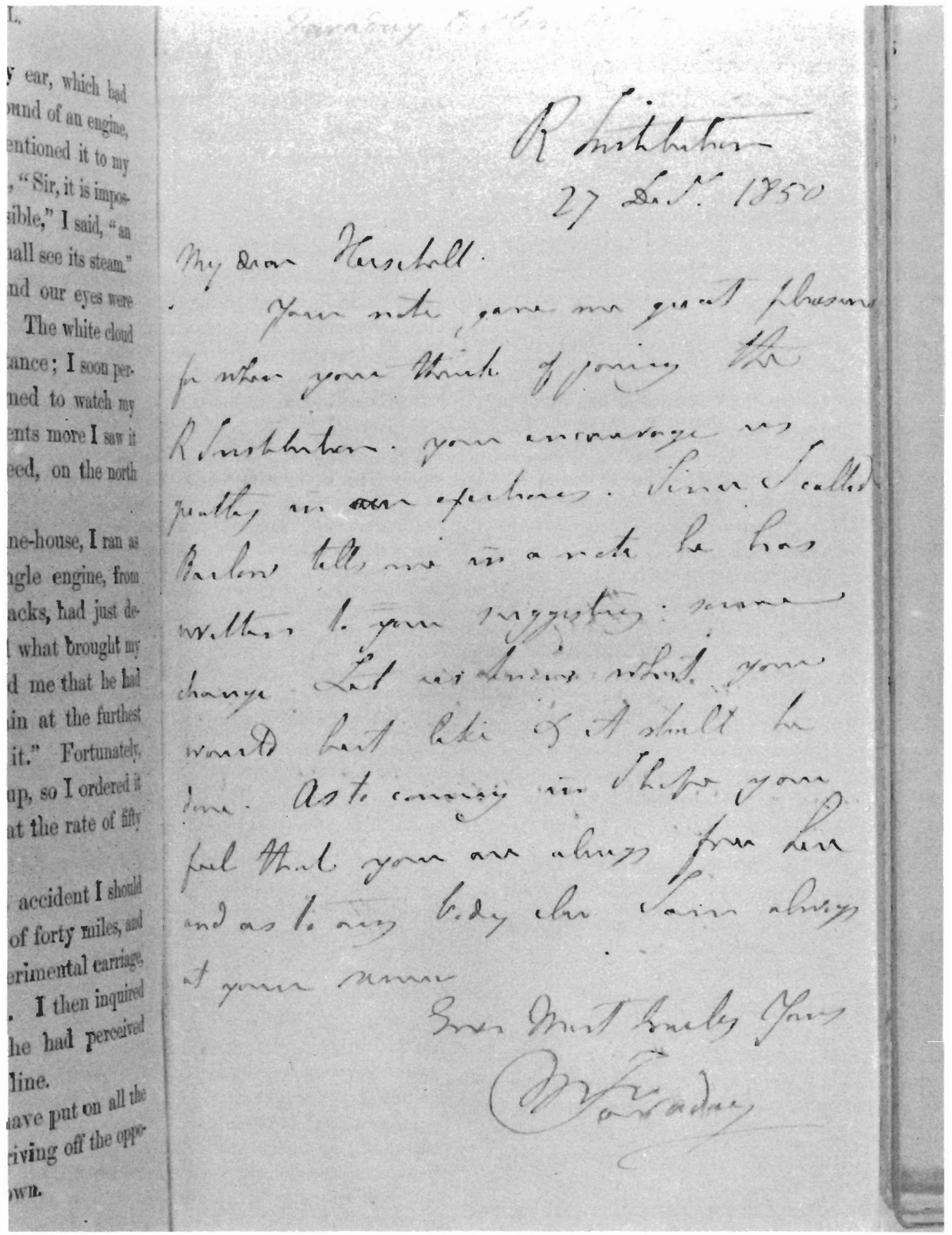

Figure 8. Letter of Michael Faraday to John Hersche1, 27 December 1850, bound into Charles Babbage, Passages from the Life of a Philosopher, 1864 (MS 173). 
Professor of Geology, whose collection of early printed books on geology is now in the Osler Library.

Regarding scientists of international fame who were associated with McGill, the name of Ernest Rutherford naturally comes to mind. Thirty-eight letters and two postcards from Rutherford to Eve discovered in the Macdonald Physics Building in the 1970's are now in the Archives. $^{32}$ A large documentation has been assembled there and in the Rutherford Museum, covering the period of Rutherford's teaching career at McGill (1898-1907) and his later activities, with copies of his correspondence. Above all, the apparatus which he used in his experiments at McGill is still extant.

Experiments by Rutherford and Frederick Soddy are recorded in the minute-books of the McGill Physical Society. Seven volumes covering the years 1857 to 1959 are preserved in the Archives.

The extensive collection of papers concerning Sir William Osler contains not only his correspondence and personal and family papers but also numerous documents relating to his professional activities as a physician, teacher and author. It is housed in the library bearing his name. A summary description is given in $A$ Guide to Arcbival Resources at McGill University.

An important connection with science in Russia is provided by the papers left by Boris Petrovich Babkin, a renowned physiologist. He had in his youth been Ivan Pavlov's assistant, remained a close friend throughout the latter's life, and became the author of Pavlov's biography. ${ }^{33}$ In exile from his country since 1922, he began teaching at McGill's Faculty of Medicine in 1928. From his retirement in 1942 until his death in 1950, he continued his work as an associate of the Montreal Neurological Institute. The documents preserved in the Osler Library include his correspondence with Pavlov and his family. Full records of his experiments and correspondence with his colleagues are kept in the University Archives.

The collection of documents concerning Wilder Penfield's life and work, preserved at the Montreal Neurological Institute, is a unique source for the history of neurology and neurosurgery. A detailed inventory listing most of the papers is available there, taking account of his various activities, his correspondence, events of his life and his writing.

Evidence of links between defense research and naticinal politics is contained in the papers of Otto Maass, MacDonald Professor of Physical Chemistry from 1923 and, until his retirement in 1955, Director of the Pulp and Paper Research Institute of Canada. Preserved in the University Archives, the Maass papers contain letters to and from Lester Pearson on NATO and the nuclear deterrent.

The University Archives also house the papers of Donald Hebb, professor of psychology from 1947 and Chancellor of the University, 1970-1972. They concern his work as a psychologist and are of particular interest in view of the influence of his book, The Organization of Bebavior ${ }^{34}$, on what was later to be called neuroscience.

Lastly, attention must be drawn to the wealth of material, preserved in the Osler Library, concerning the life and work of Norman Bethune, whose memory is revered in contemporary China. There are many letters (copies and not a few originals) of various periods; there are case records made during the time he worked in the Royal Victoria Hospital; and there is evidence of his activity as Secretary of the Montreal Group for the Security of the People's Health ("an open letter to all potential candidates seeking election in Montreal" in 1936), and an album with miscellaneous photographs illustrating his life in China.

\section{(VI) Special Collections}

No adequate impression could be gained of the nature and the wealth of the treasures preserved at McGill without taking account of its many special collections some of which are noted below. A survey with detailed descriptions is urgently required. No more than a few preliminary remarks can be given here.

It is a pleasure to record that several major collections are in a satisfactory state, readily accessible to users:

The Rosalynde Stearn Puppet Collection, outstanding for its antique puppets and more than 2700 volumes on puppets from many countries, is accessible through its published catalogue. ${ }^{35}$ 


\section{Hidden Treasures at McGill}

Through the catalogue (mentioned above) ${ }^{36}$ of its 60,000 volumes, the resources of the BlackerWood Library of Zoology and Ornithology are known to scholars. As noted above, the collection includes thousands of letters among which is one by Audubon, as well as many drawings and paintings of animals. Among the latter are 35 paintings of birds by the young Edward Lear, one of which has lately been reproduced on a stamp by the British Post Office.

The Frank Dawson Adams collection numbering over 1500 volumes on geology and on early science, now in the Osler Library, is fully catalogued.

The remarkable Colgate collection, kept in the Colgate Room (RBD), contains 13,300 items on the history of the book and of printing as well as many examples of fine print.

The Wainw right collection housed in the Law Library contains over 800 books, mostly by French jurists from the sixteenth to the nineteenth century or by writers on French legal history. ${ }^{37}$ They are accessible through the general catalogue of the Law Library.

The greater part of the Lande collection of rare Canadiana is accessible through privately printed catalogues. ${ }^{38}$ Checklists of two small collections, one concerning the Moravian mission to the Eskimos of Labrador, the other concerning manuscript material on the Canadian Indians and the Pacific North West Coast, appeared in 1973 and 1974 . The catalogue of the Lande-Arkin collection concerning Western Canada is yet to come.

Work on the important collection of historical maps has been in progress for some time. It contains, apart from several particularly rare items, over 5000 sheet maps and over 500 folded maps from the sixteenth century to recent times as well as over 300 atlases, only partly catalogued. A systematic catalogue will undoubtedly be generally welcomed.

McGill was fortunate in acquiring in 1980 the collection of over 500 volumes amassed by Gregor Malantschuk in Copenhagen whose aim was to reconstruct Kierkegaard's library by acquiring a copy of each book known to have been read by him. In addition, he collected works on Kierkegaard which appeared after his death. The catalogue which has been produced ${ }^{39}$ does not make a distinction between these two categories nor does it list separately the books owned by Kierkegaard himself. The user interested in the latter has to go through the whole catalogue before identifying the seven copies which were clearly Kierkegaard's own and the six others which, on good evidence, are assumed to have been his. These 13 books include, for instance, a copy of Hegel's Pbänomenologie des Geistes (Berlin 1832) and the Vorlesungen über die Pbilosopbie der Religion, nebst einer Schrift über die Beweise vom Daseyn Gottes (Berlin 1840) as well as a copy of Jakob Boehme's Hobe und tieffe Grïnde von dem dreyfachen Leben des Menschen (Amsterdam 1660).

1t is due to the skill of Dr. Hans Möller, formerly Director of McGill University Libraries, now editor of Fontanus, that this precious collection could be transferred from Copenhagen to McGill. Professor Alastair McKinnon, the author of many studies on Kierkegaard, informed me that he will supply the missing introduction to the catalogue. These scholars will no doubt draw attention to the special interest attached to some of the books now in RBD, once owned by Kierkegaard, such as Thomasine Gyllembourg-Ehrensvärd's novel on two eras To Tidsaldre: Novelle, Copenhagen 1845 , which he annotated.

Less fortunate have so far been the collections described below.

Of major interest to the historian are the Redpath Tracts, a collection of over 20,000 pamphlets related to British history from the middle of the sixteenth to the end of the nineteenth century, concerning historical events and politics as well as religion and theology. Of the nine series, seven are bound in approximately 1200 volumes. One series is contained in over 100 boxes and one, comprising over 500 items, is unbound

For the first two series there are author cards in the RBD catalogue together with a chronological list of many of the others. A complete bibliographical listing of this important source material has been desired for a long time. It is welcome news that large parts of it have now been entered into various databases.

Mention should be made of the small unlisted collection of seals of monarchs (i.e. Queen 
Elizabeth I, Charles I, James VI, Queen Victoria), princes, popes and freemasons, preserved in RBD.

For the large collection of about 2400 autograph letters in many languages, there is at least a list of authors and addressees in RBD.

Whereas the William Blake collection (given by Lawrence Lande to McGill) is now known through a recently published catalogue (McGill University, 1983), several other collections concerning English literature, such as the more than four hundred volumes given by Dr. Sydney T. Fisher (which includes a copy of a Fourth Folio Shakespeare), are not yet catalogued. The same is true of Sir E.K. Chambers' Shakespeare collection, the books by and about Robert Louis Stevenson given by Norman Friedman, as well as those by and about Malcolm Lowry. Lists are kept in RBD.

A collection of nearly 8000 Canadian pamphlets of the nineteenth and twentieth century arranged in alphabetical order is not yet catalogued.

It is surprising to find that a collection of 172 volumes which belonged to Charlotte Trottier Desrivières, née Guillimin, who became James McGill's wife in 1776, still remains unlisted and unarranged. Although it is unlikely to contain any rarities, the collection would show what kind of books formed the library of a woman of French Canadian origin.

Still uncatalogued, too, are the 26 volumes, mostly French books of the late eighteenth and early nineteenth century, once owned by the leader of the 'patriots,' Louis Joseph Papineau.

For the interesting Napoleon collection consisting of over 3500 prints, a manuscript catalogue, written by Mr. Richard Pennington in loose-leaf binders, is kept in the Print Room. Over 1000 rare books concerning Napoleon are kept in RBD.

The Bewick collection regarding Thomas and John Bewick and volumes containing examples of their work includes many nineteenth-century woodblocks some of which have been taken to be the Bewicks' early work. It is uncatalogued. A critical report by Christopher Heppner is found in The Book Collector, Spring 1986, "A Collection of Woodblocks and related Material at McGill University."
A provisional catalogue to the outstanding Hume collection is kept in RBD. A definitive catalogue demands special expertise due to the complicated problems of eighteenth-century bibliography. It would have to include also such minor items as a check signed by Hume and references to the notes made by later owners of Hume's works. It would be of great value to the students of Hume.

Particular problems are presented by the Oriental collections (other than the Islamic ones). It may be expected that the still uncatalogued over 400 Chinese and Japanese books will be rendered accessible, once the proposed exchanges with scholars of these countries bear fruit. The same applies to the rich collection of palm-leaf manuscripts, mostly Sinhalese ('olas'), which are still unlisted. A fairly large collection of Assyrian and Babylonian documents requires a systematic study by specialists.

In 1981, McGill received an unusual gift, a collection of 2275 volumes of Yiddish literature of the twentieth century, generously donated by the family of the late Joe Fishstein. It is outstanding both by its size and by the great number of rare items which are found only in a few libraries in the world. The collection includes many samples of books published in Eastern Europe before 1939, most copies of which were destroyed during the war. It also preserves some of the rare Yiddish imprints published in the Soviet Union after the war. It is especially valuable for its beautifully designed editions of Yiddish poetry, some of which are illustrated by well-known artists such as the young Marc Chagall and El Lissitski.

Joe Fishstein, who assembled this collection, was by profession a worker in the New York garment industry, at one time a maker of buttonholes. By his flair and the originality of his approach, by the soundness of his judgement and his lifelong dedication to the task of preserving a threatened cultural heritage, he set a shining example to future collectors and lovers of books.

The collection is, alas, largely uncatalogued. We express the hope that a Maecenas may soon come forward in Montreal who, by providing the funds required for an adequate description of each item, will help to make this heritage of 
a vanished world accessible to an interested public.

A benefactor might also consider providing the means to catalogue the still unlisted collection of Hebrew books assembled by the late Rabbi Lewin, which includes several imprints of the eighteenth century.

Of particular interest to the student of Greek and Latin literature is the collection of 5600 pamphlets on classical philology and on Greek and Roman authors formed, in the second part of the last century, by Otto Ribbeck (1827-1898), a scholar well-known for his edition of Virgil and of the fragments of Roman playwrights as well as for his history of Roman poetry and many learned articles. Like the young Nietzsche, he was a pupil of Friedrich Ritschl whose biography he wrote. A predecessor of Nietzsche as holder of the chair of classics at Basle, his name occurs in the correspondence between Nietzsche's close friend and ally, Erwin Rohde (who was his guest at Heidelberg) and Nietzsche.

The collection is indicative of the state of scholarship and the trends of research in Nietzsche's time. It contains many items not found anywhere else in Canada nor, presumably, in most libraries of this Continent. Almost all items are in German or in Latin. However, there are a few others such as some numbers of the Bibliotheca Platonica, published at Osceola, Missouri, which he evidently received as editor of the well-known periodical Rbeinisches Museum für Philologie. The Bibliotheca Platonica, describing e.g. how the Platonists of some small towns in the Mid-West celebrated Plato's birthday, is a curiosum of some interest for the history of Platonism in the nineteenth century. According to information obtained from the National Library in Ottawa, this remarkable publication is not found in any other Canadian library.

This collection, acquired well over 80 years ago (when Sir William Peterson, himself a classical scholar, was Principal of McGill), is still uncatalogued. As far as the wealth of unbound material is concerned, there can be no doubt that it would be in the interest of scholarship in Canada that the means be found to awaken this precious collection of Nietzsche's time from its long slumber.

\section{(VII) France, Germany, Italy}

The foregoing pages give some samples of the wealth of documents preserved at McGill. Not to prolong this survey unduly, the manuscripts and historical documents concerning countries other than those treated above will be dealt with in a future article.

The documents concerning France include a series of charters signed by French kings, the originals of no fewer than twelve of Rousseau's published letters and autographs of many literary figures such as George Sand and Renan. Special interest attaches to two manuscripts of the eighteenth century, which were central in antireligious polemic, the famous Traite des Trois Imposteurs and the copy (not, as has been stated erroneously, the original) of the Essai de métaphisique [sic] dans le principe de $B^{* * *}$ de Spinosa attributed to Comte Henri de Boulainviller (followed by La vie de Spinosa par Lucas and L'esprit de Spinosa).

Among the German collection, four unpublished letters by Rainer Maria Rilke, the first dating from 8 November 1896 and addressed to Gabriele Reuter - a precursor of the women's movement - after the publication of her novel Aus guter Familie, merit special attention. A list will also be given of the so far unnoticed short autographs of Alexander von Humboldt, and of the historians von Raumer, Ranke and Mommsen. Attention will be drawn to an unpublished letter of 15 April 1865 from Adalbert Stifter, asking for a prolongation of leave from his duties as inspector of schools ('Schulrat'), on account of his cancerous illness, as well as to a communication from Schliemann dispatched from "Troy near the Dardanelles." Mention will be made of two folders containing typescripts of poems by Bertolt Brecht, with a few corrections. Apart from such literary documents, the collection contains many hitherto unnoticed historical documents, ranging from a letter of 1514 by Emperor Maximilian 1 to charters of Bavarian princes of the eighteenth century.

Among the many items relating to Italy, mention may be made of a seventeenth-century manuscript of Machiavelli, "copied to denounce the poison spread in it," and an elaborate list compiled by the Censor's Office in Florence during the second quarter of the nineteenth century, of publications which were forbidden 
to circulate in the Grand-Dukedom of Tuscany (Libri stati proibiti dalla Censura di Firenze).

Especially remarkable, as mentioned above, is the extraordinary wealth of original documents concerning Venice, including many State Papers, issued by the Doges from the late thirteenth to the eighteenth century.

Mention must also be made of the documents of lesser importance concerning the United States, Spain, Ireland and Sweden.

This survey should not end without expressing the writer's thanks to the heads of the various special libraries and, in particular, to Dr. Richard Virr, Curator of Manuscripts in the Department of Rare Books and Special Collections in McLennan Library, and the staff of the Department for their valuable assistance and their unfailing courtesy, making it possible to consult an unusually large number of books in a short time. In the absence of a comprehensive catalogue, the lists kept with great care in RBD have often proved to be the sole reliable guide. I am especially grateful, moreover, to Professor Ethel Groffier of the Faculty of Law for her constant help and meticulous attention to detail.

\section{Notes}

1. A. K. Sanjian, Catalogue of Medieval Armenian Manuscripts in the United States (Berkeley, University of California Press, 1976), pp. $780-83$

2. Thomas J. Martin, North American Collections of Islamic Manuscripts (Boston, G. K. Hall, 1977), pp. 86-90.

3. A Dictionary Catalogue of the Blacker Wood Library of Zoology and Ornitbology, 9 vols. (Boston, G. K. Hall, 1966), IX, pp. 681-684.

4. H. I. Poleman, Census of Indic Manuscripts in the United States and Canada (New Haven, American Oriental Society, 1938).

5. David Berg, "A Fragmentary Book of the Dead Papyrus Belonging to McGill University,' SSEA Journal, XIII (2: 1983), pp. 107-119.

6. Seymour de Ricci with the assistance of $W$. $\mathrm{J}$. Wilson, Census of Medieval and Renaissance Manuscripts in the United States and Canada (New York, Wilson, 1937).

7. S. de Ricci, Census, p. 2203.

8. Christopher U. Faye and W. A. Bond, Supplement to the Census of Medieval and Renaissance Manuscripts in the United States and Canada (New York, Bibliographical Society of America, 1962).

9. Revised edition (Montreal, McGill University Press, 1969).

10. European and American Manuscripts (Montreal, McGill University, 1962).

11. Marcel Caya, ed., Guide to Archival Resources at McGill University, 3 vols. (Montreal, McGill University Archives, 1985).

12. B. P. Grenfell and A. S. Hunt, eds., The Oxyrbynchus Papyri, Part XIV (London, The Egypt Exploration Society, 1920), pp. 132-133.

13. William Turner, Journal of a Tour in the Levant, 3 vols. (London, 1820).

14. Peter Dronke, ed., Bernardus Silvestris: Cosmographia (Leiden, E. J. Brill, 1978).

15. David H. Weinglass, ed., Collected English Letters of Henry Fuseli (Millwood, N.Y., Kraus International Publications, 1982). 
16. Cecil Y. Lang and Edgar F. Shannon, eds., The Letters of Alfred Lord Tennyson (Cambridge, Mass., Harvard University Press, 1981).

17. Charles R. Sanders, ed., The Collected Letters of Thomas and Jane Welsh Carlyle, 12 vols. (Durham, N.C., Duke University Press, 1970).

18. Ibid., vol. 5, p. 228.

19. J. Y. T. Greig, ed., The Letters of David Hume 2 vols. (Oxford, Clarendon Press, 1932).

20. Raymond Klibansky and Ernest C. Mossner, eds., New Letters of David Hume (Oxford, Clarendon Press, 1954).

21. Horace Walpole's letter to Thomas Gray, 25 January 1766 . W. S. Lewis, ed., Walpole's Correspondence, vol. XIV (London, 1948), p. 153.

22. C.-A. Sainte-Beuve, Nouveaux lundis, vol. $1 \mathrm{~V}, 19$ janvier 1863 (Paris, Michel Lévy, 1865), pp. 178-179.

23. André-Daniel Laffon de Ladebat, Discours sur la nécessité et les moyens de détruire l'esclavage dans les colonies (Bordeaux, 1788).

24. London, printed for Henry Colburn and Co., Public Library, Conduit Street, Hanover Square, 1820.

25. Greig, op.cit., vol.1I, p. 325.

26. Sainte-Beuve, Nouveaux lundis, vol. IV, 2 février 1863 , p. 222.

27. "Notes and Comments. McGill University Library," Canadian Historical Review, XVIll (June 1936), pp. 224-227.

28. Ethel Groffier, "Deux contrats de mariage du temps du Général Montcalm," La Revue du Notariat, 91, $1 / 2$ (Sept.-Oct. 1988), pp. 60-65.

29. Dorothy M. Schullian, ed., The Baglivi Correspondence from the Library of Sir William Osler (Ithaca, Cornell University Press, 1974).

30. Dionisio Minaggio, Feather Book (Milan, 1618).

31. Acta Matbematica, V, 1885.

32. See the article by Montague Cohen, "My Dear Eve... The Letters of Ernest Rutherford to Arthur Eve, 1907-1908," Fontanus, I (1988), pp. 3-37.

33. Boris P. Babkin, Pavlov, a Biography (Chicago, University of Chicago Press, 1949).
34. Donald O. Hebb, The Organization of Behavior: A Neuropsychological Theory (New York, Wiley, 1949).

35. The Rosalynde Stearn Puppet Collection (Montreal, McGill University Library, 1961).

36. A Dictionary Catalogue of the BlackerWood Library of Zoology and Ornitbology, 9 vols. (Boston, G. K. Hall, 1966).

37. M. L. Renshawe and J. E. C. Brierley, "Sources of Civil Law: the Wainwright Collection," Fontanus, I (1988), pp. 77-83.

38. Lawrence Lande, The Lawrence Lande Collection of Canadiana in the Redpath Library of Mc Gill University: A Bibliography (Montreal, The Lawrence Lande Foundation for Canadian Historical Research, 1965).

Lawrence Lande, Rare and Unusual Canadiana; first supplement to the Lande bibliography (Montreal, McGill University, 1971).

39. Catalogue of the Gregor Malantschuk søren Kierkegaard Collection in the Department of Rare Books and Special Collections (Montreal, McGill University Libraries, 1984). 